\title{
Identification and characterization of KV7 channels within rat mesenteric endothelial cells
}

\author{
Samuel Baldwin ${ }^{1}$, Shaun Sandow ${ }^{2}$, Gema Mondejar-Parreño ${ }^{3}$, Jennifer Stott $^{4}$, and Iain \\ Greenwood $^{5}$ \\ ${ }^{1}$ St George's University of London \\ ${ }^{2}$ University on New South Wales \\ ${ }^{3}$ Universidad Complutense \\ ${ }^{4}$ St George's, University of London \\ ${ }^{5}$ St George's, University of London
}

May 27, 2020

\begin{abstract}
Background and purpose KCNQ-encoded KV7 channels are expressed within vascular smooth muscle cells (VSMCs) and are key regulators of vascular reactivity, regulating resting tone and as functional targets of endogenous responses. Endothelial cells (ECs) form a paracrine signaling platform that line all blood vessels and regulate tone, but little is known of KV7 channels in vascular ECs. This study aims to characterize the expression and function of KV7 channels within rat mesenteric artery ECs. Experimental approach In rat mesenteric artery, KCNQ transcript and KV7 channel protein expression were determined via RT-qPCR, immunocytochemistry, immunohistochemistry and immunoelectron microscopy. Wire myography was used to determine vascular reactivity. Key results KCNQ transcript was identified in EC marker expressing cells using a reductive approach. KV7.4 and KV7.5 protein expression was determined in both isolated EC and VSMC and in whole vessels. Removal of ECs attenuated vasorelaxation to two structurally different KV7.2-5 activators S-1 and ML213. KIR2 blockers ML133 and $\mathrm{BaCl}$ also attenuated S-1 or ML213-mediated vasorelaxation in an endothelium-dependent process. KV7 inhibition attenuated receptor-dependent nitric oxide (NO)-mediated vasorelaxation to carbachol, but had no impact on relaxation to the NO donor, SNP. Conclusions and implications In rat mesenteric artery ECs, KV7.4 and KV7.5 channels are expressed, functionally interact with endothelial KIR2.x channels and contribute to endogenous eNOS-mediated relaxation. This study identifies KV7 channels as novel functional channels within rat mesenteric ECs and suggests that these channels are involved in NO release from the endothelium.
\end{abstract}

\section{Identification and characterization of $K_{\mathrm{V}} 7$ channels within rat mesenteric endothelial cells}

\section{$\mathrm{K}_{\mathrm{V}} 7$ channel characterization in rat endothelial cells}

Samuel N Baldwin ${ }^{1}$, Shaun L Sandow ${ }^{2}$, Gema Mondéjar-Parreño ${ }^{3}$, Jennifer B Stott ${ }^{1}$, Iain A Greenwood ${ }^{1}$

1. Vascular Biology Research Centre, Institute of Molecular and Clinical Sciences, St George's University of London, London, UK.

2. Biomedical Science, School of Health and Sports Science, University of the Sunshine Coast, Maroochydore, and Department of Physiology, School of Medical Sciences, University of New South Wales, Sydney, Australia. 
3. Department of Pharmacology and Toxicology, School of Medicine, University Complutense of Madrid, Instituto de Investigación Sanitaria Gregorio Marañón (IiSGM), Madrid, Spain. Ciber Enfermedades Respiratorias (CIBERES), Madrid, Spain.

- SN Baldwin, SL Sandow, G Mondéjar-Parreño and JB Stott performed the research.

- IA Greenwood and JB Stott designed the research study.

- SL Sandow contributed essential reagents or tools.

- SN Baldwin, SL Sandow and G Mondéjar-Parreño analysed the data.

- SN Baldwin and IA Greenwood wrote the paper.

\section{Word count: 3186 (excluding methods)}

\section{Acknowledgements}

The authors would like to thank Miss Aditi Gunjal for her excellent assistance in wire Myography. S.N.B was funded by the British Heart Foundation (Grant \#FS/18/41/33762) awarded to I.A.G.

\section{Conflict of interest}

The authors declare no conflict of interest.

\section{Abstract \\ Background and purpose}

KCNQ-encoded $\mathrm{K}_{\mathrm{V}} 7$ channels are expressed within vascular smooth muscle cells (VSMCs) and are key regulators of vascular reactivity, regulating resting tone and as functional targets of endogenous responses. Endothelial cells (ECs) form a paracrine signaling platform that line all blood vessels and regulate tone, but little is known of $\mathrm{K}_{\mathrm{V}} 7$ channels in vascular ECs. This study aims to characterize the expression and function of $\mathrm{K}_{\mathrm{V}} 7$ channels within rat mesenteric artery ECs.

\section{Experimental approach}

In rat mesenteric artery, KCNQ transcript and $\mathrm{K}_{\mathrm{V}} 7$ channel protein expression were determined via RTqPCR, immunocytochemistry, immunohistochemistry and immunoelectron microscopy. Wire myography was used to determine vascular reactivity.

\section{Key results}

KCNQ transcript was identified in EC marker expressing cells using a reductive approach. $\mathrm{K}_{\mathrm{V}} 7.4$ and $\mathrm{K}_{\mathrm{V}} 7.5$ protein expression was determined in both isolated EC and VSMC and in whole vessels. Removal of ECs attenuated vasorelaxation to two structurally different $\mathrm{K}_{\mathrm{V}} 7.2-5$ activators S-1 and ML213. $\mathrm{K}_{\mathrm{IR}} 2$ blockers ML133, and $\mathrm{BaCl}$ also attenuated S-1 or ML213-mediated vasorelaxation in an endothelium-dependent process. $\mathrm{K}_{\mathrm{V}} 7$ inhibition attenuated receptor-dependent nitric oxide (NO)-mediated vasorelaxation to carbachol, but had no impact on relaxation to the NO donor, SNP.

\section{Conclusions and implications}

In rat mesenteric artery ECs, $\mathrm{K}_{\mathrm{V}} 7.4$ and $\mathrm{K}_{\mathrm{V}} 7.5$ channels are expressed, functionally interact with endothelial $\mathrm{K}_{\mathrm{IR}} 2 . \mathrm{x}$ channels and contribute to endogenous eNOS-mediated relaxation. This study identifies $\mathrm{K}_{\mathrm{V}} 7$ channels as novel functional channels within rat mesenteric ECs and suggests that these channels are involved in NO release from the endothelium. 


\section{Key words}

- $\mathrm{K}_{\mathrm{V}} 7$ channel

- Endothelial cell

- Vascular smooth muscle cell

- $\mathrm{K}_{\mathrm{IR}}$ channel

\section{What is already known}

$\mathrm{K}_{\mathrm{V}} 7$ channels and endothelial cells are key regulators of vascular tone.

\section{What this study adds}

- When stimulated, endothelial cell $\mathrm{K}_{\mathrm{V}} 7$ channels which interact with $\mathrm{K}_{\mathrm{IR}} 2$.x channels.

- Endothelial $\mathrm{K}_{\mathrm{V}} 7$ channels contribute to carbachol-mediated eNOS dependent relaxation.

\section{Clinical significance}

Endothelial $\mathrm{K}_{\mathrm{V}} 7$ channels represent novel targets in endothelial dysfunction.

\section{Abbreviations}

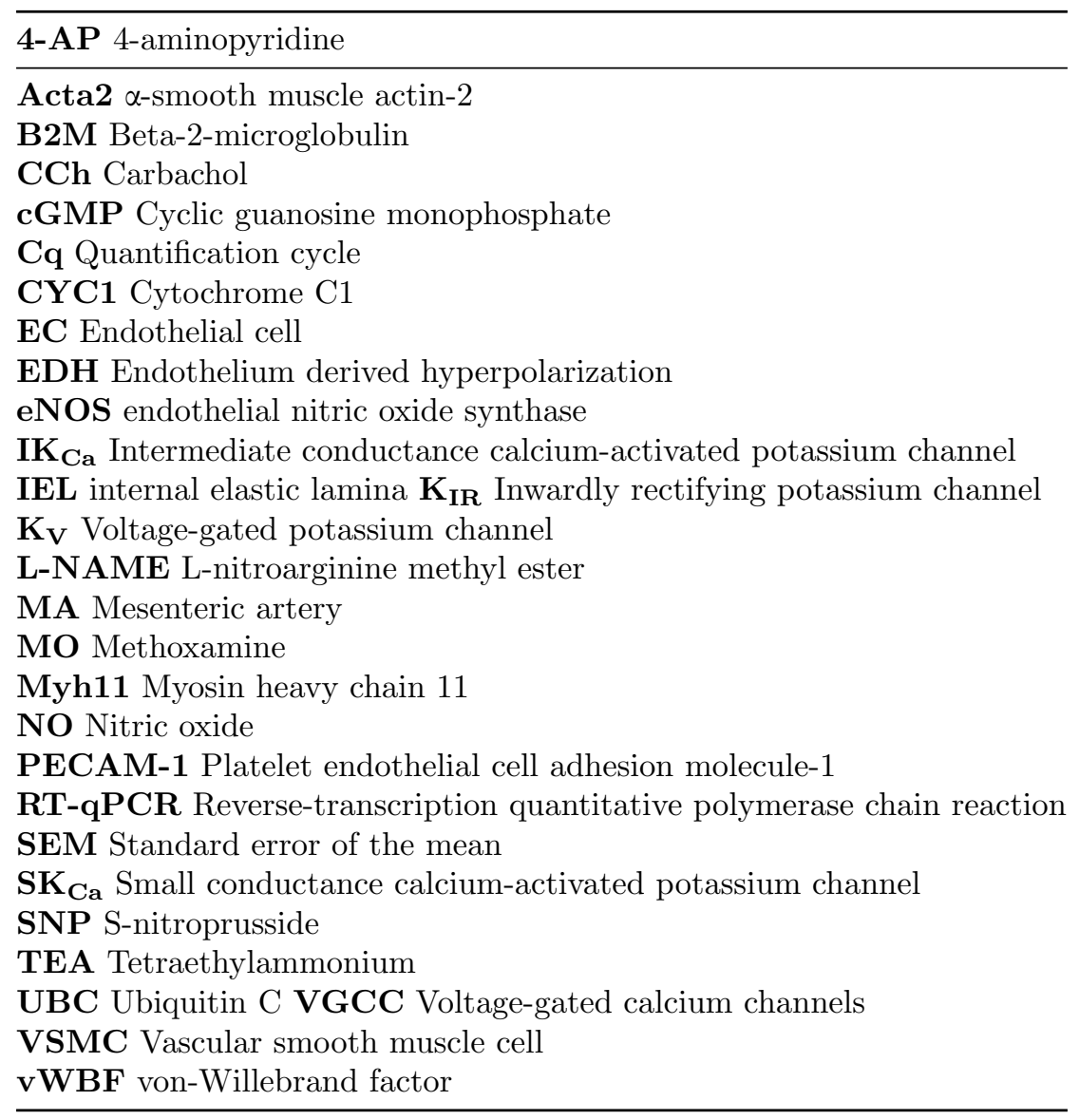




\section{Introduction}

KCNQ-encoded $\mathrm{K}_{\mathrm{V}} 7$ channels are key regulators of arterial reactivity. Of the five KCNQ subtypes, KCNQ4 is the most predominantly expressed in the vasculature, followed by KCNQ5 then KCNQ1, with little to no contribution from KCNQ2/3 (Ng et al., 2011; Ohya, Sergeant, Greenwood, \& Horowitz, 2003; Yeung et al., 2007). In human and rodent blood vessels $\mathrm{K}_{\mathrm{V}} 7$ channels contribute to resting tone (Ohya et al. , 2003; Yeung et al. , 2007; Ng et al. , 2011, Mackie et al., 2008) whereby $\mathrm{K}_{\mathrm{V}} 7$ blockers like linopirdine or XE991 produce contractions or enhance vasoconstrictor responses. In addition, a range of compounds like retigabine or S-1 that increase the activity of $\mathrm{K}_{\mathrm{V}} 7.2-7.5$ are effective relaxants of pre-contracted arteries. $\mathrm{K}_{\mathrm{V}} 7$ channels are also functional end targets for a myriad of endogenous vasoactive responses. Channel activity is impaired during PKC-mediated vasoconstriction (L. I. Brueggemann et al., 2006) and enhanced as a result of cGMP and cAMP dependent receptor-mediated vasodilatations (e.g. Chadha et al. , 2012; Khanamiri et al., 2013; Stott, Jepps and Greenwood, 2014; Stott et al. , 2015; Mani et al. , 2016; Brueggemann et al. , 2018). To date, vascular studies on $\mathrm{K}_{\mathrm{V}} 7$ channels have focused predominantly on vascular smooth muscle cells (VSMCs), and as a result it is currently unclear whether endothelial cell (EC) $\mathrm{K}_{\mathrm{V}} 7$ channels exist and if so, what their functional role may be.

The inner layer of blood vessels is comprised of ECs, which constitute a paracrine signaling platform that lines all blood vessels. These cells regulate VSMC contractility, vascular resistance and ultimately blood flow through the release of nitric oxide (NO), prostacyclin, epoxyeicosatrienoic acid and others as well as the generation and spread of endothelium-derived hyperpolarization (EDH) (McGuire, Ding, \& Triggle, 2001). Myoendothelial projections within fenestrations (holes) of the internal elastic lamina (IEL) facilitate the presence of myoendothelial gap junctions (MEGJs) at a proportion of such sites ( $~ 50 \%$ in adult rat $1^{\text {st }}-3^{\text {rd }}$ order 'large' mesenteric arteries; MA; (Sandow et al., 2009). Such junctions facilitate heterocellular electrochemical coupling via connexins at junction sites (Sandow, Senadheera, Bertrand, Murphy, \& Tare, 2012). Ultimately, MEGJs enable EC-derived signaling pathways via the flow of both small molecules $<\sim 1 \mathrm{kDa}$ and selective currents between cell types. Within rat MA EC-derived vasorelaxant microdomain signaling cascades, previous data has implicated fundamental roles for small/intermediate conductance calcium-activated potassium channels $\left(\mathrm{SK}_{\mathrm{Ca}}\right.$ and $\mathrm{IK}_{\mathrm{Ca}}$, respectively; (Sandow, Neylon, Chen, \& Garland, 2006); Dora et al., 2008 Circ Res), transient receptor potential canonical type 3 channels (Senadheera et al., 2012), inositol1,3,4 trisphosphate receptor/s (Sandow CEPP 2009), and inwardly rectifying potassium channels $\left(\mathrm{K}_{\mathrm{IR}} 2\right.$ ) (Goto, Rummery, Grayson, \& Hill, 2004). More recently, within mouse MA, $\mathrm{K}_{\mathrm{IR}} 2.1$ has been identified as a propagator of EC derived signals, acting as a hyperpolarization 'booster' (Sonkusare, Dalsgaard, Bonev, \& Nelson, 2016).

Despite the contribution of $\mathrm{K}_{\mathrm{V}} 7$ channels to baseline VSMC tension and receptor-mediated responses, their expression and function within ECs remains relatively unknown. This study shows that $\mathrm{K}_{\mathrm{V}} 7$ channels are expressed in rat mesenteric ECs and contribute to both $\mathrm{K}_{\mathrm{V}} 7$ activator mediated vasorelaxation via a novel functional interaction with $\mathrm{K}_{\mathrm{IR}} 2$ channels and endothelial nitric oxide synthase (eNOS)-dependent carbachol $(\mathrm{CCh})$-mediated vasorelaxation.

\section{Methods}

\section{Animal models}

Experiments were performed on mesenteric arteries from Male Wistar rats (Charles River, Margate, UK) ages 11-14 weeks (200-350 g) from the Biological Research Facility, St George's, London, UK; and from the Animal Resources Center, Perth, Australia. Animals were housed in cages with free access to water and food (RM1; Dietex Inter-national, UK) ad libitum, with a 12-hour light/dark cycle and constant temperature and humidity $\left(21 \pm 1^{\circ} \mathrm{C} ; 50 \% \pm 10 \%\right.$ humidity) in accordance with the Animal (Scientific Procedures) Act 1986, the guidelines of the National Health and Medical Research Council of Australia and the UNSW Animal Ethics and Experimentation Committee (AEEC \#18/86B). Animals were kept in a bedding of LSB Aspen 
woodchip. Animals were culled by either cervical dislocation with secondary confirmation via cessation of the circulation by femoral artery severance or were anaesthetized with sodium pentathol (intraperitoneal, $100 \mathrm{mg} / \mathrm{kg}$ ) in accordance with Schedule 1 of the ASPA 1986.

Either whole mesenteric plexus or $2^{\text {nd }} / 3^{\text {rd }} / 4^{\text {th }}$ order MA were used with vessel order identified from the second bifurcation of the superior mesenteric artery. Arteries were dissected, cleaned of fat and adherent tissue and stored on ice within physiological salt solution (PSS) of the following composition (mmol- $\mathrm{L}^{-1}$ ); $119 \mathrm{NaCl}, 4.5 \mathrm{KCl}, 1.17 \mathrm{MgSO}_{4} .7 \mathrm{H}_{2} 0,1.18 \mathrm{NaH}_{2} \mathrm{PO}_{4}, 25 \mathrm{NaHCO}_{3}, 5$ glucose, $1.25 \mathrm{CaCl}_{2}$.

\section{Reverse transcription quantitative polymerase chain reaction}

To investigate gene expression in fresh ECs we used a subtractive approach rather than generating pure native EC samples. Relative fold-changes in expression levels of VSMC/EC markers and Kcnqtranscript was determined in denuded MA samples (an EC(-) population) compared to whole MA samples (an EC(+) population) via Reverse transcription quantitative polymerase chain reaction (RT-qPCR).

EC(-) MA samples were prepared as described previously (Askew Page et al., 2019); Briefly, vessels were cut open longitudinally and pinned on a Sylgard dish, the lumen of the vessel was then rubbed with human hair, and vessels washed in $0.1 \%$ (phosphate buffered saline) PBS-Triton X for $1 \times 1$ min, then 3 times in PBS (1 minute each) on ice. $\mathrm{EC}(+)$ MA samples were whole MA plexus that had not undergone EC removal as above.

mRNA from both whole MA EC(+) and MA EC(-) was extracted using Monarch Total RNA Miniprep Kit (New England BioLabs, Ipswich, Massachusetts, USA) with a LunaScript RT SuperMix Kit (New England BioLabs, Ipswich, Massachusetts, USA). Quantitative analysis of relative gene expression was assessed via CFX-96 Real-Time PCR Detection System (BioRad, Hertfordshire, UK). Samples were run in duplicate to account for variation. Samples were run in BrightWhite qPCR plate (Primer Design, Camberley, UK), with each well containing $20 \mu \mathrm{L}$ of reaction solution containing: $10 \mu \mathrm{L}$ of PrecisionPLUS qPCR Master Mix (Primer Design, Camberley, UK), 300 nmol-L ${ }^{-1}$ of gene specific target primer (Thermofisher scientific, Waltham, Massachusetts, USA) and $10 \mathrm{ng}$ of cDNA sample made up to $20 \mu \mathrm{L}$ total volume with nuclease free water. Run protocol: 1 . activation step $\left(15 \mathrm{~min}: 95^{\circ} \mathrm{C}\right)$, 2 . denaturation step $\left(15 \mathrm{sec}: 94^{\circ} \mathrm{C}\right)$, 3. annealing step $\left(30\right.$ sec: $\left.55^{\circ} \mathrm{C}\right)$ and 4 . extension step $\left(30\right.$ sec: $\left.70^{\circ} \mathrm{C}\right)$. Steps $2-4$ were repeated x 40 . Quantification cycle (Cq) was determined via Bio-Rad CFX96 Manager 3.0. Values are Cq values normalised to housekeeper

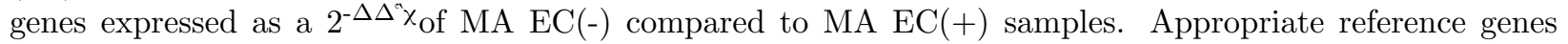
including ubiquitin $\mathrm{C}$ (UBC), cytochrome $\mathrm{C} 1$ (CYC1) and Beta-2-microglobulin (B2M; Primer design, UK) were determined using qbase+ PCR analysis system (Biogazelle, Ghent, Belgium) geNorm programme. See Table 1.1 for a list of the primers used in the following (Askew Page et al., 2019; Thomas A. Jepps et al., 2011); ThermoFisher Scientific).

\section{Immunocytochemistry}

$2^{\text {nd }}$ and $3^{\text {rd }}$ order MA segments were enzymatically digested to obtain freshly isolated ECs as previous (Greenberg et al., 2016). Briefly, vessels were washed in Hanks' Balanced Salt Solution (HBSS; ThermoFisher Scientific, GIBCO, 14170-088) containing $50 \mu$ mol- $\mathrm{L}^{-1} \mathrm{CaCl}_{2}$ for 5 min at $37^{\circ} \mathrm{C}$ and then placed in $1 \mathrm{mg} / \mathrm{mL}$ collagenase IA (Sigma Aldrich, C9891, UK) in the same solution for $15 \mathrm{~min}$ at $37^{\circ} \mathrm{C}$. Vessel were washed in HBSS containing $50 \mu \mathrm{mol}-\mathrm{L}^{-1} \mathrm{CaCl}_{2}$ for $10 \mathrm{~min}$ at $37^{\circ} \mathrm{C}$. The supernatant was removed and the vessels cells suspended in fresh HBSS containing $0.75 \mathrm{mmol}-\mathrm{L}^{-1} \mathrm{CaCl}_{2}$. ECs were dissociated using a wide-bore smooth-tipped pipette. The cell-containing solution was plated onto coverslips and left at RT for $1 \mathrm{~h}$ before use. 
Freshly dispersed ECs, together with residual VSMC, were fixed in $4 \%$ paraformaldehyde (Sigma-Aldrich, UK ) in PBS for 20 min at RT as previously described (Barrese, Stott, Figueiredo, et al., 2018). Cells were treated with 0.1 mol- $\mathrm{L}^{-1}$ glycine for 5 min and incubated for $1 \mathrm{~h}$ with blocking solution (PBS-0.1\% Triton $\mathrm{X}-100-10 \%$ bovine serum albumin) at RT. Following the incubation overnight at $4^{\circ} \mathrm{C}$ with primary antibodies (Table 1.2) diluted in blocking solution (anti-PECAM-1 for ECs, anti- $\alpha$-actin for VSMCs and anti-K 7.4 or $\mathrm{K}_{\mathrm{V}} 7.5$ channel for ECs/VSMCs), cells were then washed for $20 \mathrm{~min}$ with PBS, incubated for $1 \mathrm{hr}$ at RT with the secondary conjugated antibodies diluted in blocking solution. Excess secondary antibody was removed by washing with PBS and mounted using media containing DAPI for nuclei counterstaining. Using triple staining, ECs and VSMC were differentiated via the following: ECs were positive for anti-CD31 (endothelial cell-specific marker) and negative for anti- $\alpha$-actin (data not showed); while VSMC was positive for anti- $\alpha$ actin and negative for anti-PECAM-1 (data not showed). Cells were analysed using a Zeiss LSM 510 Meta argon/krypton laser scanning confocal microscope (Image Resource Unit St George's University of London).

\section{Immunohistochemistry}

Animals were anaesthetized with sodium pentathol (intraperitoneal, $100 \mathrm{mg} / \mathrm{kg}$ ) and perfusion fixed (Sandow, Goto, Rummery, \& Hill, 2004) in $2 \%$ paraformaldehyde in $0.1 \mathrm{~mol}-\mathrm{L}^{-1}$ PBS. Third to $4^{\text {th }}$ order mesenteric artery segments were dissected, opened laterally and pinned as a sheet to a Sylgard dish. Segments were washed in PBS ( $3 \times 5$ min), incubated in blocking buffer (PBS with $1 \%$ BSA and $0.2 \%$ Triton) at room temperature (RT) for $2 \mathrm{~h}$ and then overnight with primary antibody (Table 1.2) in blocking buffer at $4^{\circ} \mathrm{C}$, washed again $(3 \times 5 \mathrm{~min}$ with gentle agitation), and incubated in secondary antibody (Table 1.2; matched to the respective primary) in PBS with $0.1 \%$ Triton in PBS for $2 \mathrm{~h}$ at RT. Tissue was mounted on slides in anti-fade media containing propidium iodide (PI) or 4',6-diamidino-2-phenylindole (DAPI; Table 1.2) and imaged with uniform confocal settings. Incubation of tissue with secondary only was used as a 'zero' setting for confocal imaging. Controls involved substitution of primary with isotype control, with concentration (where provided by manufacturer) matched, or 10-fold higher than the respective antibody of interest (Table 1.2). Working Ab dilutions were prepared in accordance with previous work (Chadha et al., 2012; Thomas A. Jepps, Greenwood, Moffatt, Sanders, \& Ohya, 2009). Confocal image stacks were collected at $0.2 \mu \mathrm{m}$ intervals. The optimal rinsing protocol was determined by incubating in secondary only; and rinsing after successive $5 \mathrm{~min}$ incubations until fluorescence was reduced to background. Note that if this was not done secondary alone was specifically highly localized to IEL hole sites; as potential false positives at such sites; suggesting that such sites have an affinity for IgG-secondary label alone.

\section{Immunoelectron microscopy}

Animals were anaesthetized as above and perfusion fixed in $0.2 \%$ glutaraldehyde and $2 \%$ paraformaldehyde in 0.1 mol- $\mathrm{L}^{-1} \mathrm{PBS}(\mathrm{pH} 7.4)$. Mesenteric artery segments $(\sim 2 \mathrm{~mm}$ in length) were washed $(3 \times 5 \mathrm{~min})$ and processed in a Leica EMPACT 2 high-pressure freezer using $0.7 \%$ low melting agarose as a cryoprotectant. Samples were then freeze-substituted in a Leica AFS2 into 0.2\% uranyl acetate in 95\% acetone (from -85 to $\left.-50^{\circ} \mathrm{C}\right)$ and infiltrated with Lowicryl $\left(\right.$ at $\left.-50^{\circ} \mathrm{C}\right)$, before UV polymerization $\left(2 \mathrm{~d}\right.$ each at -50 and $20^{\circ} \mathrm{C}$; (Zechariah et al., 2020).

Individual serial transverse sections $(\sim 100 \mathrm{~nm})$ were mounted on Formvar-coated slot grids and processed for antigen localization as for confocal immunohistochemistry (per above and Table 1.2). The secondary used was 5 or $10 \mathrm{nmol}-\mathrm{L}^{-1}$ colloidal gold-conjugated antibody $(1: 40 ; 2 \mathrm{~h})$ in $0.01 \%$ Tween-20. Sections were imaged at x10-40,000 on a JEOL transmission electron microscope at 16 MP (Emsis, Morada G3). Background gold label density was determined from randomly selected (4 x) $1 \times 1 \mu \mathrm{m}$ regions per sample of lumen and IEL, compared to the same sized regions of interest in the endothelium. 


\section{Wire Myography}

$2^{\text {nd }}$ order MA segments ( $2 \mathrm{~mm}$ in length) were mounted on $40 \mu \mathrm{m}$ tungsten wire in a tension myograph chamber (Danish Myo Technology, Arhus, Denmark) containing $5 \mathrm{~mL}$ of PSS (composition, as above) oxygenated with $95 \% \mathrm{O}_{2}$ and $5 \% \mathrm{CO}_{2}$ at $37^{\circ} \mathrm{C}$. Vessels then underwent a passive force normalization process to achieve an internal luminal circumference at a transmural pressure of $100 \mathrm{mmHg}(13.3 \mathrm{kPa})$ to standardize pre-experimental conditions (Mulvany, 1977). Force generated was first amplified by a PowerLab (ADInstruments, Oxford, UK), and recorded by LabChart software (ADInstruments, Oxford, UK). Vessels were then challenged with $60 \mathrm{mM}\left[\mathrm{K}^{+}\right]$to determine viability. Vessels were then constricted with $10 \mu \mathrm{mol}-$ $\mathrm{L}^{-1}$ methoxamine, an $\alpha-1$ adrenoreceptor agonist, and EC integrity determined via addition of $10 \mu \mathrm{mol}^{-\mathrm{L}^{-1}}$ CCh. Vessels displaying [?] $90 \%$ vasorelaxation in response to CCh $\left(10 \mu \mathrm{mol}-\mathrm{L}^{-1}\right)$ were considered EC positive $(\mathrm{EC}+)$. Vessels were denuded of ECs by gently passing a human hair through the lumen. Vessels expressing [?]10\% vasorelaxation in response to $\mathrm{CCh}\left(10 \mu \mathrm{mol}-\mathrm{L}^{-1}\right)$ were considered EC negative (EC-). During functional investigations, all vessels were pre-constricted with the thromboxane A2 receptor agonist U46619 (300 nmol- $\left.\mathrm{L}^{-1}\right)$ to elicit an $\mathrm{EC}_{80}$ contraction. Concentration-dependent relaxant responses to S-1 (0.1-10 $\mu$ mol$\left.\mathrm{L}^{-1}\right)$, ML213 (0.1-10 $\left.\mu \mathrm{mol}-\mathrm{L}^{-1}\right)$, ML277 (0.03-1 $\left.\mu \mathrm{mol}-\mathrm{L}^{-1}\right)$, CCh $\left(0.3-10 \mu \mathrm{mol}-\mathrm{L}^{-1}\right)$ and S-nitroprusside (SNP; 0.01-3 $\left.\mu \mathrm{mol}-\mathrm{L}^{-1}\right)$ were determined in the presence and absence of ECs, linopirdine (10 $\left.\mu \mathrm{mol}-\mathrm{L}^{-1}\right)$, HMR-1556 $\left(10 \mu \mathrm{mol}-\mathrm{L}^{-1}\right)$, ML133 $\left(20 \mu \mathrm{mol}-\mathrm{L}^{-1}\right)$, barium chloride $\left(\mathrm{BaCl} ; 100 \mu \mathrm{mol}-\mathrm{L}^{-1}\right)$, L-nitroarginine methyl ester (L-

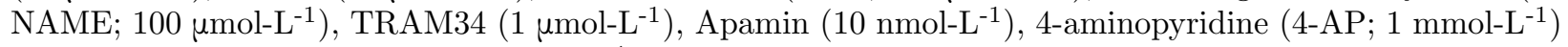
and tetraethylamonium (TEA; 1 mmol- $\left.\mathrm{L}^{-1}\right)$.

\section{Dara and statistical analysis}

All functional figures express mean data from at least 5 animals \pm standard error of the mean (SEM). For functional experiments involving cumulative concentrations, a transformed data set was generated using; $\mathrm{X}=\log (\mathrm{X})$, to reduce representative skew. A four parametric linear regression analysis was then performed using the following equation; ( $\log$ (Agonist) vs. response - variable slope (four parameters bottom/hillslope/top/EC 50 )) using GraphPad Prism (Version 8.2.0) to fit a CEC to the figure. For data comparing multiple groups, a two way-ANOVA followed by a post hoc Bonferonni test, to account for type 1 errors in multiple comparisons was performed for comparison of mean values. Significance values are represented as follows; $P<0.05(*)$. The data and statistical analysis comply with the recommendations on experimental design and analysis in pharmacology (Curtis et al., 2018).

\section{Results}

\section{Identification of $\mathrm{K}_{\mathrm{V}} 7$ channels within MA ECs}

Initial investigation sought to identify $\mathrm{K}_{\mathrm{V}} 7.4$ and $\mathrm{K}_{\mathrm{V}} 7.5$ channel transcript and protein within MA ECs, as these subtypes are implicated in vascular reactivity (Barrese et al, 2018). Transcript levels for EC and VSMC markers were determined in cell lysates from MA with and without EC removal by mechanical abrasion (see Methods). In cell suspensions from EC-denuded vessels there was a reduction in EC markers (Pecam/Vwbf ) and an increase in VSMC markers (Acta2/Myh11) compared to lysates from unabraded MA (Figure 1). This was associated with a 1.8- and 2.1-fold decrease in relative transcript abundance of Kcnq4 and Kcnq5, (Figure 1) showing that a considerable component of these transcripts were derived from EC cells. This data suggests expression of Kcnq4 and Kcnq5 within EC marker expressing cells (Figure 1).

$\mathrm{K}_{\mathrm{V}} 7.4$ was $\mathrm{K}_{\mathrm{V}} 7.5$ was detected in isolated ECs by immunodetection (Figure 2A,C). $\mathrm{K}_{\mathrm{V}} 7.4$ had a punctate distribution in isolated ECs (Figure $2 \mathrm{~A}$ ) whereas $\mathrm{K}_{\mathrm{V}} 7.5$ label appeared to be predominantly cytoplasmic with some diffuse label around the nucleus (Figure 2C). Similar to previous reports (Zhong et al. , 2010; Oliveras et al. , 2014; Mills et al. , 2015; Morales-Cano et al. , 2015, Barrese et al., 2018) KV 7.4 and 7.5 were identified in isolated MA VSMCs (Figure 2B,D). Notably, $\mathrm{K}_{\mathrm{V}} 7.4$ and $\mathrm{K}_{\mathrm{V}} 7.5$ were also detected in both ECs 
and VSMCs inen face whole-mount tissue (Figure 2.E-H). $\mathrm{K}_{\mathrm{V}} 7.4$ was also detected in EC by immunoelectron microscopy (supplemental figure 1). Further, both $\mathrm{K}_{\mathrm{V}} 7.4$ and 7.5 were expressed at a proportion of IEL hole sites at an apparently higher level than the associated EC membrane label (Figure 3).

Removal of ECs modulates $\mathrm{K}_{\mathrm{V}} 7.2-5$ activator efficacy

A comprehensive pharmacological analysis was undertaken to determine if $\mathrm{K}_{\mathrm{V}} 7$ channels have a functional role in MA ECs. Effects of $\mathrm{K}_{\mathrm{V}} 7$ channel modulators were examined in MAs where the endothelium was intact or had been removed. S-1 and ML213 are structurally dissimilar activators of $\mathrm{K}_{\mathrm{V}} 7.2-7.5$ that interact with the same pharmacophore centered around a tryptophan in the S5 domain (Bentzen et al., 2006; Lyubov I. Brueggemann, Haick, Cribbs, \& Byron, 2014; T. A. Jepps et al., 2014; Schenzer, 2005). ML277 is a potent activator of $\mathrm{K}_{\mathrm{V}} 7.1$ (Yu, 2013) with a 100-fold increase in selectivity for $\mathrm{K}_{\mathrm{V}} 7.1$ compared to $\mathrm{K}_{\mathrm{V}} 7.2$ 5 (Yu, 2013). Consistent with previous findings (Chadha et al., 2012; T. A. Jepps et al., 2014), S-1- and ML213-mediated vasorelaxation was ablated by pre-incubation with $10 \mu \mathrm{mol}-\mathrm{L}^{-1}$ pan-K $\mathrm{K}_{\mathrm{V}}$ channel inhibitor linopirdine (Schnee \& Brown, 1998); Figure 4.A,B). Relaxations produced by 10 to $300 \mathrm{nmol}-\mathrm{L}^{-1}$ ML277 were also prevented by incubation with linopirdine (Figure 4C). However, relaxations produced by concentrations $>1 \mu \mathrm{mol}-\mathrm{L}^{-1}$ ML277 were not attenuated by linopirdine and are therefore not mediated by Kv7.1 activation.

EC removal for the following experiments was confirmed by ablation of vasorelaxation in response to 10 $\mu$ mol- $\mathrm{L}^{-1} \mathrm{CCh}$ (Figure 5A). Removing the endothelium by mechanical abrasion has no impact on the peak contraction produced by $300 \mathrm{nmol}-\mathrm{L}^{-1} \mathrm{U} 46619$ (Figure 4B), but significantly attenuated the potency of S-1 mediated vasorelaxation increasing $\mathrm{EC}_{50}$ from $2 \pm 0.2 \mu \mathrm{mol}-\mathrm{L}^{-1}$ to $3 \pm 0.7 \mu \mathrm{mol}-\mathrm{L}^{-1}$ (Figure $5 \mathrm{C}, \mathrm{D}$ ). The potency of ML213 was also impaired by endothelial removal $\left(\mathrm{EC}(+) \mathrm{EC}_{50}=1 \pm 0.2 \mu\right.$ mol-L ${ }^{-1}$ vs $\mathrm{EC}(-) \mathrm{EC}_{50}$ $=3 \pm 0.2 \mu \mathrm{mol}-\mathrm{L}^{-1}$; Figure $5 \mathrm{E}$ ). The linopirdine-sensitive relaxation produced by ML277 was not affected by endothelial removal (Figure 5F). The accumulated findings reveal that ECs express $\mathrm{K}_{\mathrm{V}} 7.4$ and $\mathrm{K}_{\mathrm{V}} 7.5$ and the presence of the endothelium enhances the sensitivity of two structurally different $\mathrm{K}_{\mathrm{V}} 7.2-7.5$ activators.

$\mathrm{IK}_{\mathrm{Ca}} / \mathrm{SK}_{\mathrm{Ca}}$ inhibitors have no impact on $\mathrm{K}_{\mathrm{V}} 7$ activator mediated relaxation

Having identified that the endothelium modulates responses to Kv7 activators, experiments were performed to identify the mechanism/s involved. Endothelial $\mathrm{IK}_{\mathrm{Ca}}$ and $\mathrm{SK}_{\mathrm{Ca}}$ channels contribute to relaxation responses in rat MA (Crane, Gallagher, Dora, \& Garland, 2003). Thus, it is feasible that $K_{V} 7$ channels interact with other key endothelial potassium channels; particularly in microdomains (Sandow et al., 2009). However, in agreement with previous reports (T. A. Jepps, Olesen, Greenwood, \& Dalsgaard, 2016), pre-incubation with

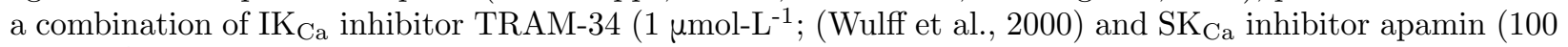
nmol-L ${ }^{-1}$; (Spoerri, Jentsch, \& Glees, 1975) had no effect on $\mathrm{K}_{\mathrm{V}} 7$ activator mediated vasorelaxation (Figure $6 \mathrm{~A}-\mathrm{C})$.

EC $\mathrm{K}_{\mathrm{ir}}$ channels modulate $\mathrm{K}_{\mathrm{V}} 7.2-5$ activator sensitivity

Within MAs of a EC-K $\mathrm{IR}_{\mathrm{IR}} 2.1-/-$ murine model, endothelial KCNJ2-encoded $\mathrm{K}_{\mathrm{IR}} 2.1$ channels have been identified as 'signal boosters' that enhance EC-derived relaxation (Sonkusare et al., 2016). Comparatively, the current literature regarding rat mesenteric $\mathrm{K}_{\mathrm{IR}} 2$ channels is limited; with $\mathrm{K}_{\mathrm{IR}} 2.1$ expression being demonstrated in EC of whole mount rat MA (Dora, Gallagher, McNeish, \& Garland, 2008), where inwardly rectifying $\mathrm{Ba}^{2+}$ sensitive channels are apparently restricted to the endothelial layer (Crane, Walker, Dora, \& Garland, 2003), and $\mathrm{K}_{\mathrm{IR}}$ channels contribute to acetylcholine-mediated responses (Goto et al., 2004). We propose that like mice, rat mesenteric ECs express functional $\mathrm{K}_{\mathrm{IR}} 2$ channels that propagate EC signals in a similar process. Therefore, we performed a series of studies investigating the effect of two well characterized $\mathrm{K}_{\mathrm{IR}} 2$ blockers, $\mathrm{BaCl}_{2}$ (Hagiwara, Miyazaki, Moody, \& Patlak, 1978) and ML133 (Wang et al., 2011; Wu et al., 2010) on $\mathrm{K}_{\mathrm{V}} 7$ activator-mediated vasorelaxation.

In arteries with a functional endothelium, $\mathrm{K}_{\mathrm{IR}} 2$ blockers, BaCl $\left(100 \mu \mathrm{mol}-\mathrm{L}^{-1}\right)$ and ML133 $\left(20 \mu \mathrm{mol}^{-\mathrm{L}^{-1}}\right)$, significantly impaired vasorelaxation by S-1 (Figure 7A, $\mathrm{EC}_{50}=\mathrm{DMSO}, 1.89 \pm 0.2 \mu \mathrm{mol}-\mathrm{L}^{-1} / \mathrm{BaCl}, 2.3 \pm 0.31$ $\mu \mathrm{mol}-\mathrm{L}^{-1}$; Figure $7 \mathrm{~B}, \mathrm{EC}_{50}=\mathrm{DMSO}, 0.52 \pm 0.12 \mu \mathrm{mol}-\mathrm{L}^{-1} / \mathrm{ML133}, 3.1 \pm 1.5 \mu \mathrm{mol}-\mathrm{L}^{-1}$, and ML213, Figure $7 \mathrm{C}, \mathrm{D}, \mathrm{EC}_{50}=\mathrm{DMSO}, 0.9 \pm 0.3 \mu \mathrm{mol} / \mathrm{L}^{-1} / \mathrm{BaCl}, 2.2 \pm 0.5 \mu \mathrm{mol} / \mathrm{L}^{-1} / \mathrm{ML} 133,2.5 \pm 0.25 \mu \mathrm{mol}-\mathrm{L}^{-1}$ ) when 
compared to DMSO solvent control (Figure 7A-D). No attenuation of the response to ML277 was observed consistent with EC removal data. In arteries where the endothelium had been removed neither ML133 nor $\mathrm{BaCl}$ had any effect on ML213 mediated vasorelaxation (Figure $7 \mathrm{G}, \mathrm{H}$ ). These data show that the endothelium-dependent increase in potency to the $\mathrm{K}_{\mathrm{V}} 7$ activators involves endothelial $\mathrm{K}_{\mathrm{IR}}$ channels, but not $\mathrm{IK}_{\mathrm{Ca}}$ or $\mathrm{SK}_{\mathrm{Ca}}$ channels.

$\mathrm{K}_{\mathrm{V}} 7$ channels contribute to $\mathrm{CCh}$ evoked vasorelaxation

The expression of functional $\mathrm{K}_{\mathrm{V}} 7$ channels within ECs begs the question - Do they contribute to EC-derived responses? Acetylcholine produces endothelium-dependent relaxations through NO-, EDH- and prostanoiddependent mechanisms in rat MA (Parsons, Hill, Waldron, Plane, \& Garland, 1994; Peredo, Feleder, \& Adler-Graschinsky, 1997; Shimokawa et al., 1996).

A distinct rightward shift in the sensitivity to vasorelaxation in response to $\mathrm{CCh}$, a synthetic acetylcholine analogue, was produced by $100 \mu \mathrm{mol}-\mathrm{L}^{-1}$ eNOS inhibitor L-NAME when compared to DMSO solvent control $\left(\mathrm{EC}_{50}\right.$ DMSO $=0.59 \pm 0.1 \mu \mathrm{mol}-\mathrm{L}^{-1} ; \mathrm{L}-\mathrm{NAME}=0.94 \pm 0.1 \mu \mathrm{mol}-\mathrm{L}^{-1} ;$ Figure $\left.8 \mathrm{~A}\right)$. A combination $\mathrm{IK}_{\mathrm{Ca}}$ and $\mathrm{SK}_{\mathrm{Ca}}$ inhibitors, $1 \mu \mathrm{mol}-\mathrm{L}^{-1}$ TRAM34 and $100 \mathrm{nmol}-\mathrm{L}^{-1}$ apamin, respectively produced greater attenuation $\left(\mathrm{EC}_{50}\right.$ TRAM34/apamin $=1.5 \pm 0.7 \mu \mathrm{mol}-\mathrm{L}^{-1}$; Figure 8A). These results show that both NO- and EDHdependent signaling contributes to CCh-mediated vasodilation, though the main contributor to endothelialdependent vasodilation in $2^{\text {nd }}$ order MA appears to be EDH, conferring with previously published data (Shimokawa et al., 1996). Pre-incubating vessels with $10 \mu \mathrm{mol}-\mathrm{L}^{-1}$ pan- $\mathrm{K}_{\mathrm{V}} 7$ channel inhibitor linopirdine significantly attenuated CCh-mediated vasorelaxation when compared to DMSO control $\left(\mathrm{EC}_{50}\right.$ DMSO = $0.2 \pm 0.08 \mu \mathrm{mol}-\mathrm{L}^{-1}$; linopirdine $=0.7 \pm 0.3 \mu \mathrm{mol}^{-\mathrm{L}^{-1}}$; Figure $\left.8 \mathrm{~B}\right)$. In contrast, pre-incubating vessels with either the $\mathrm{K}_{\mathrm{V}} 7.1$ specific inhibitor HMR-1556 (10 $\mu \mathrm{mol}^{-1} \mathrm{~L}^{-1}$; Figure $\left.8 \mathrm{C}\right)$ or a combination of non-specific

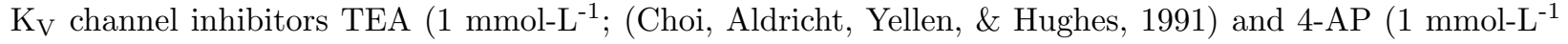
; (Kurata \& Fedida, 2006) had no significant effect on CCh-evoked vasorelaxation. These results imply a specific contribution of $\mathrm{K}_{\mathrm{V}} 7.4$ and $\mathrm{K}_{\mathrm{V}} 7.5$ channels to CCh-evoked relaxation in $2^{\text {nd }}$ order rat MA.

Subsequent experiments explored whether linopirdine affected CCh-induced relaxations in the presence of L-NAME compared to responses in apamin/TRAM34. CCh-evoked relaxations were significantly attenuated in vessels pre-incubated in TRAM34/apamin and linopirdine compared to vessels only pre-incubated in TRAM34/apamin alone $\left(\mathrm{EC}_{50} \mathrm{DMSO}=0.24 \pm 0.05 \mu \mathrm{mol}_{-} \mathrm{L}^{-1}\right.$; TRAM34/Apamin $=0.27 \pm 0.03 \mu \mathrm{mol}^{-\mathrm{L}^{-1}}$; TRAM34/Apamin + linopirdine $=0.61 \pm 0.2 \mu \mathrm{mol}-\mathrm{L}^{-1}$; Figure $8 \mathrm{E}$ ). In contrast, linopirdine failed to attenuate $\mathrm{CCh}$ relaxations in arteries pre-incubated with L-NAME (Figure $8 \mathrm{~F}$ ). These data suggest that $\mathrm{K}_{\mathrm{V}} 7.4$ and $\mathrm{K}_{\mathrm{V}} 7.5$ channels contribute to the NO pathway of CCh-mediated vasorelaxation.

$\mathrm{K}_{\mathrm{V}} 7$ channels contribute to NO-mediated vasorelaxation in a vascular bed specific manner (Jennifer B. Stott et al., 2015). The present data demonstrate that pre-incubation with the pan- $\mathrm{K}_{\mathrm{V}} 7$ channel blocker linopirdine $\left(10 \mu \mathrm{mol}-\mathrm{L}^{-1}\right)$ has no effect on vasorelaxation produced by the NO-donor s-nitroprusside (SNP; Figure 8G). However, in contrast with previous reports (T. A. Jepps et al., 2016), pre-incubation with L-NAME $\left(100 \mu \mathrm{mol}_{-} \mathrm{L}^{-1}\right)$ significantly attenuated $\mathrm{K}_{\mathrm{V}} 7.2-5$ activator mediated vasorelaxation (Figure $8 \mathrm{H}$ ). These data suggest that the NO axis of CCh-mediated vasorelaxation is linopirdine sensitive, upstream of NO signaling.

\section{Discussion}

The present study identified Kcnq4 and Kcnq5 transcripts within EC marker expressing cells as well as respective $\mathrm{K}_{\mathrm{V}} 7.4$ and $\mathrm{K}_{\mathrm{V}} 7.5$ protein in isolated and whole mount rat MA ECs/VSMCs, consistent with previous studies in the endothelium (Chen, Li, Hiett, \& Obukhov, 2016) and vascular smooth muscle (e.g Zhong et al. , 2010; Oliveras et al. , 2014; Mills et al. , 2015, summarised in Barrese et al ., 2018). Functionally, the present study demonstrates that the relaxation produced by two structurally different $\mathrm{K}_{\mathrm{V}} 7.2-5$ activators, but not a $\mathrm{K}_{\mathrm{V}} 7.1$ activator, were modulated by the endothelium. These relaxations were also sensitive to 
$\mathrm{K}_{\mathrm{IR}} 2$ inhibition and suggest a novel functional interaction between $\mathrm{K}_{\mathrm{V}} 7$ channels and endothelial $\mathrm{K}_{\mathrm{IR}} 2 . \mathrm{x}$ channels. Furthermore, we have demonstrated that $\mathrm{K}_{\mathrm{V}}$ 7.4/7.5 channels contribute to the NO-mediated axis of CCh-evoked endothelium-dependent relaxations. Thus, $\mathrm{K}_{\mathrm{V}} 7$ channels are expressed within ECs, contribute to endothelium-derived responses and when pharmacologically upregulated, are functionally coupled to other EC potassium channels.

\section{$\mathrm{K}_{\mathrm{V}} 7$ channel expression and function within ECs}

Within smooth muscle, when active, $\mathrm{K}_{\mathrm{V}} 7$ channels hyperpolarize the membrane potential decreasing voltagegated calcium channel (VGCC) open probability, therefore decreasing the influx of extracellular calcium, with this decrease resulting in relaxation of the cell. Within rodent models, the pharmacopeia of $\mathrm{K}_{\mathrm{V}} 7$ channel modulators has revealed $\mathrm{K}_{\mathrm{V}} 7.4$ and $\mathrm{K}_{\mathrm{V}} 7.5$ channels; 1 . contribute to resting vascular tone via regulation of the resting membrane potential; 2. are upregulated during cGMP and cAMP/EPAC/PKAmediated vasodilation, and; 3 . are supressed via PKC-mediated vasoconstriction. Conjunctly, the use of molecular techniques has revealed that $\mathrm{K}_{\mathrm{V}} 7.4 / \mathrm{K}_{\mathrm{V}} 7.5$ is the most predominant heterotetramer expressed within specific rodent arteries. Comparatively, no functional role for $\mathrm{K}_{\mathrm{V}} 7.1$ in arteries has been identified (see (Byron \& Brueggemann, 2018; Barrese et al , 2018), for review). A caveat of these observations is a lack of differentiation between VSMCs and ECs. However, $\mathrm{K}_{\mathrm{V}} 7$ channels were recently identified in pig coronary artery ECs (Chen et al., 2016) where they modulate bradykinin-evoked endothelium-derived vasorelaxation (Chen et al., 2016). The data presented here demonstrate $\mathrm{K}_{\mathrm{V}} 7$ channel expression in rat mesenteric endothelium and support their functional role.

In most arteries, the endothelium and smooth muscle are electrochemically linked via MEGJs formed from connexin proteins within heterocellular communicating microdomains (see (Sandow et al., 2012) for review). Via these connections, it has been purported that current injection into ECs passes into VSMCs (Sandow, Tare, Coleman, Hill, \& Parkington, 2002). As $\mathrm{K}_{\mathrm{V}} 7$ channels are expressed within rat mesenteric ECs, the present data suggest a potential role for this process in $\mathrm{K}_{\mathrm{V}} 7$ activator-mediated vasorelaxation. This conjecture is supported by a significant attenuation of vasorelaxation of pre-constricted arterial tone by two structurally different $\mathrm{K}_{\mathrm{V}} 7.2-5$ activators in the absence of ECs. In contrast, EC removal had no impact on $\mathrm{K}_{\mathrm{V}} 7.1$ activator-mediated vasorelaxation, suggesting that only $\mathrm{K}_{\mathrm{V}} 7.4$ and $\mathrm{K}_{\mathrm{V}} 7.5$ channels are functionally expressed within MA ECs. However, Chen et al, (2016) suggest that endothelial removal had no impact on ML213-mediated relaxation in pig coronary artery segments. Consequently, these collective data suggest that this phenomenon is both animal and artery bed specific, potentially being dependent on the molecular architecture of the vessel, such as MEGJ and related microdomain properties.

\section{A novel functional interaction with endothelial $\mathrm{K}_{\mathrm{IR}}$ channels}

$\mathrm{K}_{\mathrm{IR}} 2 . \mathrm{x}$ channels have been characterized in a variety of rat vascular beds including cerebral and coronary arteries (Smith et al., 2008), where their selective inhibition by $\mathrm{Ba}^{2+}$ revealed $\mathrm{K}_{\mathrm{IR}}$ channel amplification of a $\mathrm{K}^{+}$channel activator conductance (Smith et al., 2008). However, there is a degree of conflict regarding the role of $\mathrm{K}_{\mathrm{IR}} 2 . \mathrm{x}$ channels within rat MAs. As above, a $\mathrm{Ba}^{2+}$ sensitive current and $\mathrm{K}_{\mathrm{IR}} 2 . \mathrm{x}$ expression has been demonstrated in rat MA ECs (Crane, Walker, et al., 2003; Smith et al., 2008). Furthermore, within primary MA $\mathrm{K}_{\mathrm{IR}} 2 . \mathrm{x}$ channels were purported to contribute to $\mathrm{K}_{\mathrm{Ca}}$ mediated-hyperpolarization during ACh-derived EC-dependent responses (Goto et al., 2004). In contrast, Smith et al. , (2008) demonstrate that within $3^{\text {rd }}$ order MA ACh-mediated $\mathrm{K}^{+}$conductance-dependent vasorelaxation was insensitive to $\mathrm{Ba}^{2+}$, indicating that $\mathrm{K}_{\mathrm{IR}} 2 . \mathrm{x}$ channels do not augment $\mathrm{K}^{+}$conductance in these vessels during receptor-mediated vasodilation.

In the present study, significant attenuation of both S-1 and ML213 $\mathrm{K}_{\mathrm{V}} 7.2-5$ activator-mediated vasorelaxation was found after pre-incubation in two structurally different $\mathrm{K}_{\mathrm{IR}} 2 . \mathrm{x}$ blockers ML133 (Wu et al., 2010) and $\mathrm{Ba}^{2+}$ (Hagiwara et al., 1978). ML133 has been identified via high-throughput and mutagenesis investigation as a novel inhibitor of $\mathrm{K}_{\mathrm{IR}} 2.1$ channels with an $\mathrm{IC}_{50}$ of $1.8 \mu$ mol- $\mathrm{L}^{-1}$ at $\mathrm{pH} 7.4$, with little to no selectivity against the other members of the $\mathrm{K}_{\mathrm{IR}} 2$.x family (Wang et al., 2011; Wu et al., 2010) where it 
exerts its activity via D172 and I176 within the M2 region of $\mathrm{K}_{\mathrm{IR}} 2.1$ (Wang et al., 2011). Presently, ML133 is the most selective inhibitor of the $\mathrm{K}_{\mathrm{IR}} 2$ family. In parallel to the endothelium denudation experiments, no effect was seen on the $K_{V} 7.1$ activator ML277-mediated vasorelaxation; implying a specific interplay with $\mathrm{K}_{\mathrm{V}} 7.4$ and $\mathrm{K}_{\mathrm{V}} 7.5$ channels. Furthermore, $\mathrm{K}_{\mathrm{IR}} 2$ blockers had no effect on $\mathrm{K}_{\mathrm{V}}$ 7.2-7.5 activator-mediated relaxation in EC-denuded arteries, supporting the notion that functional $\mathrm{K}_{\mathrm{IR}} 2$ channels (in the rat MA bed) are restricted to the endothelium (Crane, Walker, et al., 2003), and the agents do not inhibit $\mathrm{K}_{\mathrm{V}} 7$ channels per se. The present study suggests that pharmacological activation of endothelial $\mathrm{K}_{\mathrm{V}} 7.4 / 7.5$ channels also activates an endothelial $\mathrm{K}_{\mathrm{IR}} 2$ channel increased $\mathrm{K}^{+}$conductance, which in turn accounts for a significant degree of the EC augmentation of $\mathrm{K}_{\mathrm{V}} 7.2-5$ activator-mediated vasorelaxation (Figure 11). However, based on the findings described by Goto et al,. (2004) and Smith et al,. (2008), the collective data suggest that this phenomenon is dependent on the branch order of MA. Furthermore, it remains unclear if this occurs during receptor mediated signaling, or that is only present during pharmacological activation of endothelial $\mathrm{K}_{\mathrm{V}} 7$ channels.

A primary concern for identification of novel functional interactions between ion channels using pharmacological tools is off-target effects. However, $\mathrm{K}_{\mathrm{V}} 7$ activator-mediated vasorelaxation in vessels pre-incubated in $10 \mu \mathrm{mol}-\mathrm{L}^{-1}$ linopirdine was abolished. If S-1 or ML213 were activating other channels, i.e. e.g. $\mathrm{K}_{\mathrm{IR}}$ channels, a degree of vasorelaxation would still be observed in the presence of linopirdine. The present findings therefore suggest that both S-1 and ML213 work exclusively via $\mathrm{K}_{\mathrm{V}} 7$ channels and that a novel functional coupling of $\mathrm{K}_{\mathrm{V}} 7.4 / 7.5$ and $\mathrm{K}_{\mathrm{IR}} 2$ occurs in rat MA ECs.

\section{The contribution of $\mathrm{K}_{\mathrm{V}} 7$ channels to $\mathrm{CCh}$ evoked relaxations within rat MA}

$\mathrm{K}_{\mathrm{V}} 7$ channels contribute to cGMP mediated vasorelaxation in a vascular bed specific manner (Stott et al., 2015). Within rat aortic, renal and pulmonary arteries, overexpression models, and native VSMCs $\mathrm{K}_{\mathrm{V}} 7.4 / \mathrm{K}_{\mathrm{V}} 7.5$ have been identified as downstream targets of cGMP signaling during both isometric tension recording and whole cell current recording (Mondéjar-Parreño et al., 2019; Jennifer B. Stott et al., 2015). Conversely, $\mathrm{K}_{\mathrm{V}} 7$ channels do not contribute to NO donor SNP-mediated vasorelaxation within rat renal arteries (Jennifer B. Stott et al., 2015).

In light of the significant impact of $\mathrm{K}_{\mathrm{V}} 7$ inhibition on $\mathrm{CCh}$-mediated vasorelaxation during the suppression of EDH, the present study suggests that $\mathrm{K}_{\mathrm{V}} 7$ channels contribute to CCh-evoked NO-cGMP mediated relaxation within rat MA. Though, similar to renal arteries, $\mathrm{K}_{\mathrm{V}} 7$ channels do not represent downstream targets of $\mathrm{NO}$ signaling in rat $\mathrm{MA}$ as $\mathrm{K}_{\mathrm{V}} 7$ channel inhibition does not impair SNP-mediated relaxations. However, eNOS inhibition does impair relaxation to a $\mathrm{K}_{\mathrm{V}} 7$ activator, implying that $\mathrm{K}_{\mathrm{V}} 7$ channels are involved in the production or release of NO in response to CCh. Though this appears to be a vascular bed specific phenomenon, as L-NAME significantly impairs ML213 relaxations in pig coronary artery (Chen et al., 2016), but not rat penile artery (T. A. Jepps et al., 2016).

\section{Conclusions}

In conclusion, the present data identify a novel functional interaction between mesenteric endothelial $\mathrm{K}_{\mathrm{V}}$ 7.4/7.5 and $\mathrm{K}_{\mathrm{IR}} 2$ channels and supports the proposition that endothelial $\mathrm{K}_{\mathrm{V}} 7$ channels contribute to endogenous endothelial-derived responses. These findings highlight the complex nature of the vascular response to $\mathrm{K}_{\mathrm{V}} 7$ channel upregulation and emphasize the importance of $\mathrm{K}_{\mathrm{V}} 7$ channels to vascular signaling cascades. The present data are consistent with $\mathrm{K}_{\mathrm{V}} 7$ channels representing a novel therapeutic target in endothelial dysfunction. 


\section{References}

Askew Page, H. R., Dalsgaard, T., Baldwin, S. N., Jepps, T. A., Povstyan, O., Olesen, S. P., \& Greenwood, I. A. (2019). TMEM16A is implicated in the regulation of coronary flow and is altered in hypertension. British Journal of Pharmacology . https://doi.org/10.1111/bph.14598

Barrese, V., Stott, J. B., Figueiredo, H. B., Aubdool, A. A., Hobbs, A. J., Jepps, T. A., ... Greenwood, I. A. (2018). Angiotensin II Promotes K V 7.4 Channels Degradation Through Reduced Interaction With HSP90 (Heat Shock Protein 90)Novelty and Significance.Hypertension . https://doi.org/10.1161/HYPERTENSIONAHA.118.11116

Barrese, V., Stott, J. B., \& Greenwood, I. A. (2018). KCNQ-Encoded Potassium Channels as Therapeutic Targets. Annual Review of Pharmacology and Toxicology . https://doi.org/10.1146/annurev-pharmtox010617-052912

Bentzen, B. H., Schmitt, N., Calloe, K., Dalby Brown, W., Grunnet, M., \& Olesen, S. P. (2006). The acrylamide (S)-1 differentially affects Kv7 (KCNQ) potassium channels. Neuropharmacology . https://doi.org/10.1016/j.neuropharm.2006.07.001

Brueggemann, L. I., Moran, C. J., Barakat, J. A., Yeh, J. Z., Cribbs, L. L., \& Byron, K. L. (2006). Vasopressin stimulates action potential firing by protein kinase C-dependent inhibition of KCNQ5 in A7r5 rat aortic smooth muscle cells. AJP: Heart and Circulatory Physiology , 292 (3), H1352-H1363. https://doi.org/10.1152/ajpheart.00065.2006

Brueggemann, Lyubov I., Cribbs, L. L., Schwartz, J., Wang, M., Kouta, A., \& Byron, K. L. (2018). Mechanisms of PKA-dependent potentiation of Kv7.5 channel activity in human airway smooth muscle cells.International Journal of Molecular Sciences . https://doi.org/10.3390/ijms19082223

Brueggemann, Lyubov I., Haick, J. M., Cribbs, L. L., \& Byron, K. L. (2014). Differential activation of vascular smooth muscle Kv7.4, Kv7.5, and Kv7.4/7.5 channels by ML213 and ICA-069673. Molecular Pharmacology . https://doi.org/10.1124/mol.114.093799

Byron, K. L., \& Brueggemann, L. I. (2018). Kv7 potassium channels as signal transduction intermediates in the control of microvascular tone.Microcirculation . https://doi.org/10.1111/micc.12419

Chadha, P. S., Zunke, F., Zhu, H. L., Davis, A. J., Jepps, T. A., Olesen, S. P., ... Greenwood, I. A. (2012). Reduced KCNQ4-encoded voltage-dependent potassium channel activity underlies impaired $\beta$-adrenoceptor-mediated relaxation of renal arteries in hypertension.Hypertension , 59 (4), 877-884. https://doi.org/10.1161/HYPERTENSIONAHA.111.187427

Chen, X., Li, W., Hiett, S. C., \& Obukhov, A. G. (2016). Novel Roles for Kv7 Channels in Shaping Histamine-Induced Contractions and Bradykinin-Dependent Relaxations in Pig Coronary Arteries. PLoS ONE . https://doi.org/10.1371/journal.pone.0148569

Choi, K. L., Aldricht, R. W., Yellen, G., \& Hughes, H. (1991). Tetraethylammonium blockade distinguishes two inactivation mechanisms in voltage-activated Ki channels (quaternary ammonium ions/open channel block/ball-and-chain model). Proc. Natl. Acad. Sci. USA.

Crane, G. J., Gallagher, N., Dora, K. A., \& Garland, C. J. (2003). Small-and intermediate-conductance calcium-activated $\mathrm{K}+$ channels provide different facets of endothelium-dependent hyperpolarization in rat mesenteric artery. Journal of Physiology . https://doi.org/10.1113/jphysiol.2003.051896

Crane, G. J., Walker, S. D., Dora, K. A., \& Garland, C. J. (2003). Evidence for a differential cellular distribution of inward rectifier $\mathrm{K}$ channels in the rat isolated mesenteric artery. Journal of Vascular Research . https://doi.org/10.1159/000070713

Curtis, M. J., Alexander, S., Cirino, G., Docherty, J. R., George, C. H., Giembycz, M. A., ... Ahluwalia, A. (2018). Experimental design and analysis and their reporting II: updated and simplified guidance for 
authors and peer reviewers. British Journal of Pharmacology . https://doi.org/10.1111/bph.14153

Dora, K. A., Gallagher, N. T., McNeish, A., \& Garland, C. J. (2008). Modulation of endothelial cell KCa3.1 channels during endothelium-derived hyperpolarizing factor signaling in mesenteric resistance arteries. Circulation Research . https://doi.org/10.1161/CIRCRESAHA.108.172379

Goto, K., Rummery, N. M., Grayson, T. H., \& Hill, C. E. (2004). Attenuation of conducted vasodilatation in rat mesenteric arteries during hypertension: role of inwardly rectifying potassium channels. The Journal of Physiology , 561 (Pt 1), 215-231. https://doi.org/10.1113/jphysiol.2004.070458

Greenberg, H. Z. E., Shi, J., Jahan, K. S., Martinucci, M. C., Gilbert, S. J., Vanessa Ho, W. S., \& Albert, A. P. (2016). Stimulation of calcium-sensing receptors induces endothelium-dependent vasorelaxations via nitric oxide production and activation of IKCa channels. Vascular Pharmacology . https://doi.org/10.1016/j.vph.2016.01.001

Hagiwara, S., Miyazaki, S., Moody, W., \& Patlak, J. (1978). Blocking effects of barium and hydrogen ions on the potassium current during anomalous rectification in the starfish egg. The Journal of Physiology . https://doi.org/10.1113/jphysiol.1978.sp012338

Jepps, T. A., Bentzen, B. H., Stott, J. B., Povstyan, O. V., Sivaloganathan, K., Dalby-Brown, W., \& Greenwood, I. A. (2014). Vasorelaxant effects of novel Kv7.4 channel enhancers ML213 and NS15370.British Journal of Pharmacology , 171 (19), 4413-4424. https://doi.org/10.1111/bph.12805

Jepps, T. A., Olesen, S. P., Greenwood, I. A., \& Dalsgaard, T. (2016). Molecular and functional characterization of Kv7 channels in penile arteries and corpus cavernosum of healthy and metabolic syndrome rats.British Journal of Pharmacology . https://doi.org/10.1111/bph.13444

Jepps, Thomas A., Chadha, P. S., Davis, A. J., Harhun, M. I., Cockerill, G. W., Olesen, S. P., ... Greenwood, I. A. (2011). Downregulation of Kv7.4 channel activity in primary and secondary hypertension. Circulation . https://doi.org/10.1161/CIRCULATIONAHA.111.032136

Jepps, Thomas A., Greenwood, I. A., Moffatt, J. D., Sanders, K. M., \& Ohya, S. (2009). Molecular and functional characterization of $\mathrm{K}_{\mathrm{v}} 7 \mathrm{~K}{ }^{+}$channel in murine gastrointestinal smooth muscles. American Journal of Physiology-Gastrointestinal and Liver Physiology . https://doi.org/10.1152/ajpgi.00057.2009

Kurata, H. T., \& Fedida, D. (2006). A structural interpretation of voltage-gated potassium channel inactivation. Progress in Biophysics and Molecular Biology . https://doi.org/10.1016/j.pbiomolbio.2005.10.001

Mani, B. K., Robakowski, C., Brueggemann, L. I., Cribbs, L. L., Tripathi, A., Majetschak, M., \& Byron, K. L. (2016). Kv7.5 Potassium Channel Subunits Are the Primary Targets for PKA-Dependent Enhancement of Vascular Smooth Muscle Kv7 Currents. Molecular Pharmacology ,89 (3), $323-334$. https://doi.org/10.1124/mol.115.101758

McGuire, J. J., Ding, H., \& Triggle, C. R. (2001). Endothelium-derived relaxing factors: A focus on endothelium-derived hyperpolarizing factor(s). Canadian Journal of Physiology and Pharmacology . https://doi.org/10.1139/y01-025

Mills, T. A., Greenwood, S. L., Devlin, G., Shweikh, Y., Robinson, M., Cowley, E., ... Wareing, M. (2015). Activation of $\mathrm{K}<\mathrm{inf}>\mathrm{V}</ \mathrm{inf}>7$ channels stimulates vasodilatation of human placental chorionic plate arteries.Placenta , 36 (6), 638-644. https://doi.org/10.1016/j.placenta.2015.03.007

Mondéjar-Parreño, G., Moral-Sanz, J., Barreira, B., De la Cruz, A., Gonzalez, T., Callejo, M., ... Cogolludo, A. (2019). Activation of Kv7 channels as a novel mechanism for NO/cGMP-induced pulmonary vasodilation. British Journal of Pharmacology . https://doi.org/10.1111/bph.14662

Morales-Cano, D., Moreno, L., Barreira, B., Pandolfi, R., Chamorro, V., Jimenez, R., ... Cogolludo, A. (2015). Kv7 channels critically determine coronary artery reactivity: Left-right dif- 
ferences and down-regulation by hyperglycaemia. Cardiovascular Research ,106 (1), 98-108. https://doi.org/10.1093/cvr/cvv020

Ng, F. L., Davis, A. J., Jepps, T. A., Harhun, M. I., Yeung, S. Y., Wan, A., .. Greenwood, I. A. (2011). Expression and function of the K + channel KCNQ genes in human arteries. British Journal of Pharmacology , 162 (1), 42-53. https://doi.org/10.1111/j.1476-5381.2010.01027.x

Ohya, S., Sergeant, G. P., Greenwood, I. A., \& Horowitz, B. (2003). Molecular variants of KCNQ channels expressed in murine portal vein myocytes: A role in delayed rectifier current. Circulation Research . https://doi.org/10.1161/01.RES.0000070880.20955.F4

Oliveras, A., Roura-Ferrer, M., Solé, L., De La Cruz, A., Prieto, A., Etxebarria, A., .. Felipe, A. (2014). Functional assembly of Kv7.1/Kv7.5 channels with emerging properties on vascular muscle physiology. Arteriosclerosis, Thrombosis, and Vascular Biology . https://doi.org/10.1161/ATVBAHA.114.303801

Parsons, S. J. W., Hill, A., Waldron, G. J., Plane, T., \& Garland, C. J. (1994). The relative importance of nitric oxide and nitric oxide-independent mechanisms in acetylcholine-evoked dilatation of the rat mesenteric bed. British Journal of Pharmacology . https://doi.org/10.1111/j.1476-5381.1994.tb17136.x

Peredo, H. A., Feleder, E. C., \& Adler-Graschinsky, E. (1997). Differential effects of acetylcholine and bradykinin on prostanoid release from the rat mesenteric bed: Role of endothelium and of nitric oxide. Prostaglandins Leukotrienes and Essential Fatty Acids . https://doi.org/10.1016/S0952-3278(97)90567-6

Sandow, S. L., Goto, K., Rummery, N. M., \& Hill, C. E. (2004). Developmental changes in myoendothelial gap junction mediated vasodilator activity in the rat saphenous artery. Journal of Physiology . https://doi.org/10.1113/jphysiol.2003.058669

Sandow, S. L., Haddock, R. E., Hill, C. E., Chadha, P. S., Kerr, P. M., Welsh, D. G., \& Plane, F. (2009). What's where and why at a vascular myoendothelial microdomain signalling complex. Clinical and Experimental Pharmacology and Physiology . https://doi.org/10.1111/j.1440-1681.2008.05076.x

Sandow, S. L., Neylon, C. B., Chen, M. X., \& Garland, C. J. (2006). Spatial separation of endothelial small- and intermediate-conductance calcium-activated potassium channels (KCa) and connexins: Possible relationship to vasodilator function? Journal of Anatomy, 209 (5), 689-698. https://doi.org/10.1111/j.14697580.2006.00647.x

Sandow, S. L., Senadheera, S., Bertrand, P. P., Murphy, T. V., \& Tare, M. (2012). Myoendothelial Contacts, Gap Junctions, and Microdomains: Anatomical Links to Function? Microcirculation . https://doi.org/10.1111/j.1549-8719.2011.00146.x

Sandow, S. L., Tare, M., Coleman, H. A., Hill, C. E., \& Parkington, H. C. (2002). Involvement of myoendothelial gap junctions in the actions of endothelium-derived hyperpolarizing factor. Circulation Research . https://doi.org/10.1161/01.RES.0000019756.88731.83

Schenzer, A. (2005). Molecular Determinants of KCNQ (Kv7) K+ Channel Sensitivity to the Anticonvulsant Retigabine. Journal of Neuroscience , 25 (20), 5051-5060. https://doi.org/10.1523/JNEUROSCI.012805.2005

Schnee, M. E., \& Brown, B. S. (1998). Selectivity of linopirdine (DuP 996), a neurotransmitter release enhancer, in blocking voltage-dependent and calcium-activated potassium currents in hippocampal neurons. Journal of Pharmacology and Experimental Therapeutics .

Senadheera, S., Kim, Y., Grayson, T. H., Toemoe, S., Kochukov, M. Y., Abramowitz, J., ... Sandow, S. L. (2012). Transient receptor potential canonical type 3 channels facilitate endotheliumderived hyperpolarization-mediated resistance artery vasodilator activity.Cardiovascular Research . https://doi.org/10.1093/cvr/cvs208 
Shimokawa, H., Yasutake, H., Fujii, K., Owada, M. K., Nakaike, R., Fukumoto, Y., ... Takeshita, A. (1996). The importance of the hyperpolarizing mechanism increases as the vessel size decreases in endothelium-dependent relaxations in rat mesenteric circulation. Journal of Cardiovascular Pharmacology . https://doi.org/10.1097/00005344-199611000-00014

Smith, P. D., Brett, S. E., Luykenaar, K. D., Sandow, S. L., Marrelli, S. P., Vigmond, E. J., \& Welsh, D. G. (2008). KIR channels function as electrical amplifiers in rat vascular smooth muscle. Journal of Physiology . https://doi.org/10.1113/jphysiol.2007.145474

Sonkusare, S. K., Dalsgaard, T., Bonev, A. D., \& Nelson, M. T. (2016). Inward rectifier potassium (Kir2.1) channels as end-stage boosters of endothelium-dependent vasodilators. Journal of Physiology . https://doi.org/10.1113/JP271652

Spoerri, E., Jentsch, J., \& Glees, P. (1975). Apamin from bee venom. Effects of the neurotoxin on subcellular particles of neural cultures.FEBS Letters . https://doi.org/10.1016/0014-5793(75)80006-8

Stott, J. B., \& Greenwood, I. A. (2015). Complex role of Kv7 channels in cGMP and camp-mediated relaxations. Channels , 9 (3), 117-118. https://doi.org/10.1080/19336950.2015.1046732

Stott, Jennifer B., Barrese, V., Jepps, T. A., Leighton, E. V., \& Greenwood, I. A. (2015). Contribution of Kv7 channels to natriuretic peptide mediated vasodilation in normal and hypertensive rats.Hypertension , 65 (3), 676-682. https://doi.org/10.1161/HYPERTENSIONAHA.114.04373

Stott, Jennifer B., Jepps, T. A., \& Greenwood, I. A. (2014). KV7 potassium channels: A new therapeutic target in smooth muscle disorders.Drug Discovery Today . https://doi.org/10.1016/j.drudis.2013.12.003

Wang, H. R., Wu, M., Yu, H., Long, S., Stevens, A., Engers, D. W., ... McManus, O. B. (2011). Selective inhibition of the $\mathrm{K}$ ir2 family of inward rectifier potassium channels by a small molecule probe: The discovery, SAR, and pharmacological characterization of ML133. ACS Chemical Biology . https://doi.org/10.1021/cb200146a

Wu, M., Wang, H., Yu, H., Makhina, E., Xu, J., Dawson, E. S., ... Li, M. (2010). A potent and selective small molecule Kir2.1 inhibitor. Probe Reports from the NIH Molecular Libraries Program.

Wulff, H., Miller, M. J., Hansel, W., Grissmer, S., Cahalan, M. D., \& Chandy, K. G. (2000). Design of a potent and selective inhibitor of the intermediate- conductance $\mathrm{Ca} 2+$-activated $\mathrm{K}+$ channel, IKCa1: A potential immunosuppressant. Proceedings of the National Academy of Sciences of the United States of America . https://doi.org/10.1073/pnas.97.14.8151

Yeung, S. Y. M., Pucovsky, V., Moffatt, J. D., Saldanha, L., Schwake, M., Ohya, S., \& Greenwood, I. A. (2007). Molecular expression and pharmacological identification of a role for Kv7 channels in murine vascular reactivity. British Journal of Pharmacology ,151 (6), 758-770. https://doi.org/10.1038/sj.bjp.0707284

Yu. (2013). Identification of a novel, small molecule activator of KCNQ1 channels. In Probe Reports from the NIH Molecular Libraries Program [Internet].

Zechariah, A., Tran, C. H. T., Hald, B. O., Sandow, S. L., Sancho, M., Kim, M. S. M., ... Welsh, D. G. (2020). Intercellular Conduction Optimizes Arterial Network Function and Conserves Blood Flow Homeostasis During Cerebrovascular Challenges. Arteriosclerosis, Thrombosis, and Vascular Biology . https://doi.org/10.1161/ATVBAHA.119.313391

Zhong, X. Z., Harhun, M. I., Olesen, S. P., Ohya, S., Moffatt, J. D., Cole, W. C., \& Greenwood, I. A. (2010). Participation of KCNQ (Kv7) potassium channels in myogenic control of cerebral arterial diameter.Journal of Physiology . https://doi.org/10.1113/jphysiol.2010.192823

Tables 


\begin{tabular}{|c|c|c|}
\hline Gene & $\begin{array}{l}\text { (+) Forward primer } \\
\text { sequence (-) Reverse } \\
\text { primer sequence }\end{array}$ & Amplicon (bp) \\
\hline Myh11 & $\begin{array}{l}\text { CAGTTGGACACTATGTCXGGCA59998.1 } \\
\text { ATGGAGACAAATGCTAATCAGCC }\end{array}$ & 78 \\
\hline Acta2 & $\begin{array}{l}\text { ATCCGATAGAACACGGCANC031004.2 } \\
\text { AGGCATAGAGGGACAGCACA }\end{array}$ & 228 \\
\hline Vwbf & $\begin{array}{l}\text { GTCGGAAGAGGAAGTGGACA53B88.1 } \\
\text { GGGCACACGCATGCGCTCTGTA }\end{array}$ & 136 \\
\hline Pecam1 & $\begin{array}{l}\text { CTCCTAAGAGCAAAGAGMAAOBTI9C. } 1 \\
\text { TACACTGGTATTCCATGTCTCTGG }\end{array}$ & 100 \\
\hline Kenq4 & $\begin{array}{l}\text { GAATGAGCAGCTCCCAGXIC233477.8 } \\
\text { AAGCTCCAGCTTTTCTGCAC }\end{array}$ & 133 \\
\hline Kcnq5 & AACTGATGAGGAGGTCGXXI@001071249.3 & 120 \\
\hline
\end{tabular}

\begin{tabular}{|c|c|c|c|c|c|c|c|c|}
\hline $\begin{array}{l}\text { Reagent } \\
\text { purpose }\end{array}$ & Detail & Source & $\begin{array}{l}\text { Predicted } \\
\mathrm{MW} \\
\mathrm{kDa}\end{array}$ & Epitope & [used] & $\begin{array}{l}\text { Peptide } \\
\text { availability }\end{array}$ & $\begin{array}{l}\text { Peptide } \\
\text { availability }\end{array}$ & $\begin{array}{l}\text { Raised } \\
\text { in }\end{array}$ \\
\hline \multirow[t]{5}{*}{$\begin{array}{l}\text { Primary } \\
\text { antibodies }\end{array}$} & $\begin{array}{l}\text { Kv7.4 / } \\
\text { KCNQ4 }\end{array}$ & $\begin{array}{l}\text { NeuroMab, } \\
\text { cat no } \\
75-082,1 \\
\mathrm{mg} / \mathrm{ml}\end{array}$ & 77 & $\begin{array}{l}\text { Hu aa } 2-77, \\
\text { clone } \mathrm{N} 4 / \\
36 \mathrm{IgG}\end{array}$ & $\begin{array}{l}1: 200(5 \\
\mu \mathrm{g} / \mathrm{ml})\end{array}$ & no & no & mouse \\
\hline & $\begin{array}{l}\text { Kv7.4 / } \\
\text { KCNQ4* }\end{array}$ & $\begin{array}{l}\text { Abcam, } \\
\text { ab65797, } \\
\text { lot } \\
\text { GR94754, } \\
\text { whole } \\
\text { serum }\end{array}$ & 77 & $\mathrm{~N}^{\prime}$ domain & $\begin{array}{l}\text { 1:100 not } \\
\text { available }\end{array}$ & no & no & rabbit \\
\hline & $\begin{array}{l}\text { Kv7.5 / } \\
\text { KCNQ5* }\end{array}$ & $\begin{array}{l}\text { Millipore } \\
\text { ABN1372- } \\
\text { q2476155; } 1 \\
\mathrm{ml} / \mathrm{ml}\end{array}$ & 103 & human IgG & $\begin{array}{l}1: 100(10 \\
\mu \mathrm{g} / \mathrm{ml})\end{array}$ & no & no & rabbit \\
\hline & $\begin{array}{l}\text { PECAM-1 } \\
\text { / CD31 }\end{array}$ & $\begin{array}{l}\text { Santa Cruz } \\
\text { Biotechnol- } \\
\text { ogy, } \\
\text { Sc-1506, } \\
200 \mu \mathrm{g} / \mathrm{ml}\end{array}$ & 130 & $\begin{array}{l}699-727 \text { aa } \\
\text { at the } \\
\text { C-terminus }\end{array}$ & $\begin{array}{l}1: 100(2 \\
\mu \mathrm{g} / \mathrm{ml})\end{array}$ & - & - & goat \\
\hline & SM- $\alpha$-actin & $\begin{array}{l}\text { Sigma } \\
\text { Aldrich } \\
\text { A2547 }\end{array}$ & $\sim 42$ & N-terminal & $\begin{array}{l}\text { (1:100) not } \\
\text { available }\end{array}$ & - & - & mouse \\
\hline \multirow{2}{*}{$\begin{array}{l}\text { Nuclear } \\
\text { labels / } \\
\text { cell } \\
\text { patency } \\
\text { markers }\end{array}$} & $\begin{array}{l}\text { DAPI, } \\
\text { Vectasheild }\end{array}$ & Vectorlabs & - & $\begin{array}{l}\text { nucleic } \\
\text { acid }\end{array}$ & & - & - & - \\
\hline & $\begin{array}{l}\text { propidium } \\
\text { iodide }\end{array}$ & $\begin{array}{l}\text { Sigma, } \\
\text { P4170 }\end{array}$ & - & $\begin{array}{l}\text { nucleic } \\
\text { acid }\end{array}$ & $10 \mathrm{nM}$ & - & - & - \\
\hline
\end{tabular}




\begin{tabular}{|c|c|c|c|c|c|c|c|c|}
\hline $\begin{array}{l}\text { Reagent } \\
\text { purpose }\end{array}$ & Detail & Source & $\begin{array}{l}\text { Predicted } \\
\mathrm{MW} \\
\mathrm{kDa}\end{array}$ & Epitope & [used] & $\begin{array}{l}\text { Peptide } \\
\text { availability }\end{array}$ & $\begin{array}{l}\text { Peptide } \\
\text { availability }\end{array}$ & $\begin{array}{l}\text { Raised } \\
\text { in }\end{array}$ \\
\hline \multirow[t]{3}{*}{$\begin{array}{l}\text { Immuno- } \\
\text { histochemistry } \\
\text { secondary } \\
\text { antibodies }\end{array}$} & Mouse 568 & $\begin{array}{l}\text { Abcam, } \\
\text { ab175700, } \\
\text { lot } \\
\text { GR320062- } \\
4,2 \\
\mathrm{mg} / \mathrm{ml}\end{array}$ & - & $\operatorname{IgG}$ & $\begin{array}{l}1: 100(20 \\
\mu \mathrm{g} / \mathrm{ml})\end{array}$ & - & - & donkey \\
\hline & Rabbit 546 & $\begin{array}{l}\text { Thermofisher, } \\
\text { A-11035 }\end{array}$ & & $\operatorname{IgG}$ & $\begin{array}{l}1: 100(20 \\
\mu \mathrm{g} / \mathrm{ml})\end{array}$ & - & - & goat \\
\hline & Rabbit 633 & $\begin{array}{l}\text { Merck, } \\
\text { SAB4600132, } \\
\text { lot } \\
15 \mathrm{C} 0423,2 \\
\mathrm{mg} / \mathrm{ml}\end{array}$ & - & $\operatorname{Ig} G$ & $\begin{array}{l}1: 100(20 \\
\mu \mathrm{g} / \mathrm{ml})\end{array}$ & - & - & donkey \\
\hline \multirow{3}{*}{$\begin{array}{l}\text { Immuno- } \\
\text { cytochemistry } \\
\text { secondary } \\
\text { antibodies }\end{array}$} & Mouse 488 & $\begin{array}{l}\text { Thermofisher, } \\
\text { A21202, } 2 \\
\mathrm{mg} / \mathrm{mL}\end{array}$ & & $\operatorname{IgG}$ & $\begin{array}{l}1: 100(0.02 \\
\mathrm{mg} / \mathrm{ml})\end{array}$ & $\begin{array}{l}1: 100(0.02 \\
\mathrm{mg} / \mathrm{ml})\end{array}$ & - & donkey \\
\hline & Rabbit 568 & $\begin{array}{l}\text { Thermofisher, } \\
\text { A10042, } 2 \\
\mathrm{mg} / \mathrm{mL}\end{array}$ & & $\operatorname{IgG}$ & $\begin{array}{l}1: 100(0.02 \\
\mathrm{mg} / \mathrm{ml})\end{array}$ & $\begin{array}{l}1: 100(0.02 \\
\mathrm{mg} / \mathrm{ml})\end{array}$ & - & donkey \\
\hline & Goat 633 & $\begin{array}{l}\text { Thermofisher, } \\
\text { A21082, } 2 \\
\mathrm{mg} / \mathrm{mL}\end{array}$ & & $\operatorname{IgG}$ & $\begin{array}{l}1: 100(0.02 \\
\mathrm{mg} / \mathrm{ml})\end{array}$ & $\begin{array}{l}1: 100(0.02 \\
\mathrm{mg} / \mathrm{ml})\end{array}$ & - & donkey \\
\hline \multirow[t]{2}{*}{$\begin{array}{l}\text { Isotype } \\
\text { controls }\end{array}$} & $\begin{array}{l}\text { Mouse } \\
\text { IgG }\end{array}$ & $\begin{array}{l}\text { ThermoFisher, } \\
\text { 10400C }\end{array}$ & & $\operatorname{IgG}$ & $5 \mathrm{mg} / \mathrm{ml}$ & - & - & mouse \\
\hline & $\begin{array}{l}\text { Rabbit } \\
\text { IgG }\end{array}$ & $\begin{array}{l}\text { ThermoFisher, } \\
\text { S31235 }\end{array}$ & & $\operatorname{IgG}$ & $\begin{array}{l}10 \\
\mathrm{mg} / \mathrm{ml}\end{array}$ & - & - & rabbit \\
\hline \multirow{2}{*}{$\begin{array}{l}\text { Immunoelectro } \\
\text { mi- } \\
\text { croscopy } \\
\text { sec- } \\
\text { ondary } \\
\text { antibodies }\end{array}$} & $\begin{array}{l}\text { Au anti- } \\
\text { rabbit }\end{array}$ & $\begin{array}{l}\text { Merck, } \\
\text { G7277, } \\
\text { lot } \\
\text { SLB3882V }\end{array}$ & - & $\operatorname{IgG}$ & 1:100 & - & - & goat \\
\hline & $\begin{array}{l}10 \mathrm{~nm} \\
\text { Au anti- } \\
\text { rabbit }\end{array}$ & $\begin{array}{l}\text { Merck, } \\
\text { G7402 }\end{array}$ & - & $\operatorname{IgG}$ & $1: 100$ & - & - & goat \\
\hline
\end{tabular}

Table 1.2. Immunocyto/histochemistry reagents and use (Chadha et al., 2012; Thomas A. Jepps et al., 2009).

Abbreviations. CD31, cluster of differentiation 31; DAPI, 4',6-diamidino-2-phenylindole; PECAM, platelet endothelial cell adhesion molecule. 
Figure legends

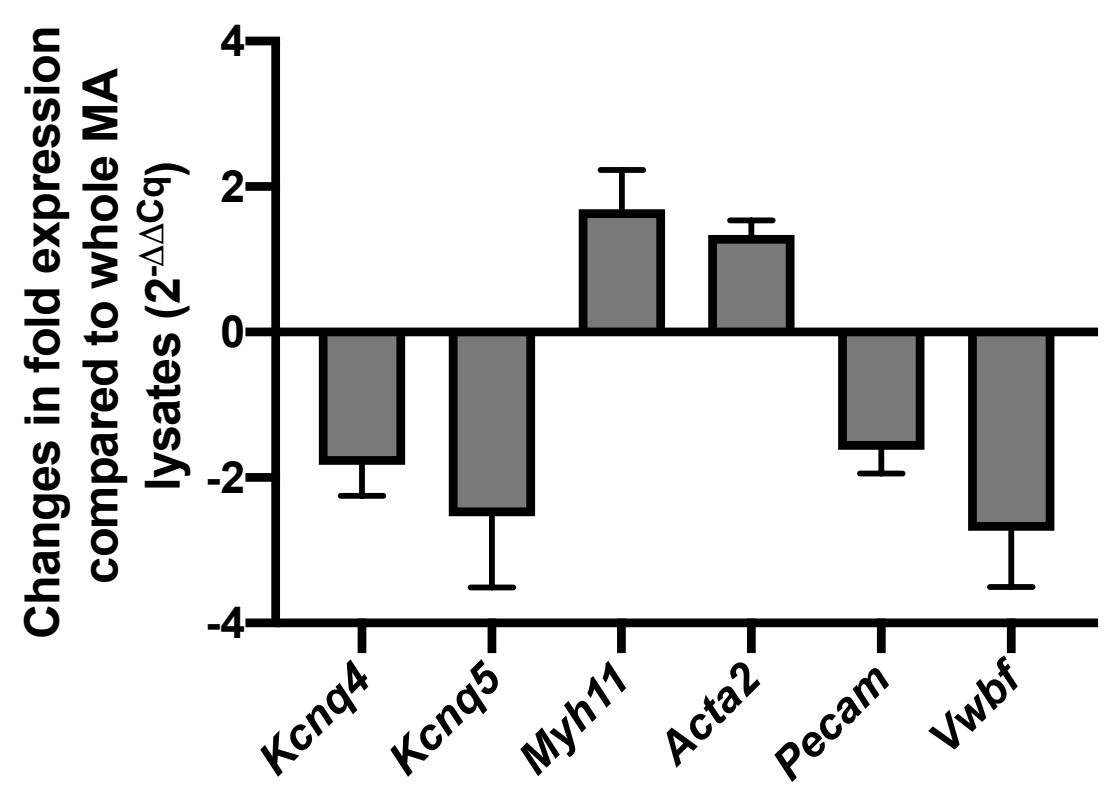




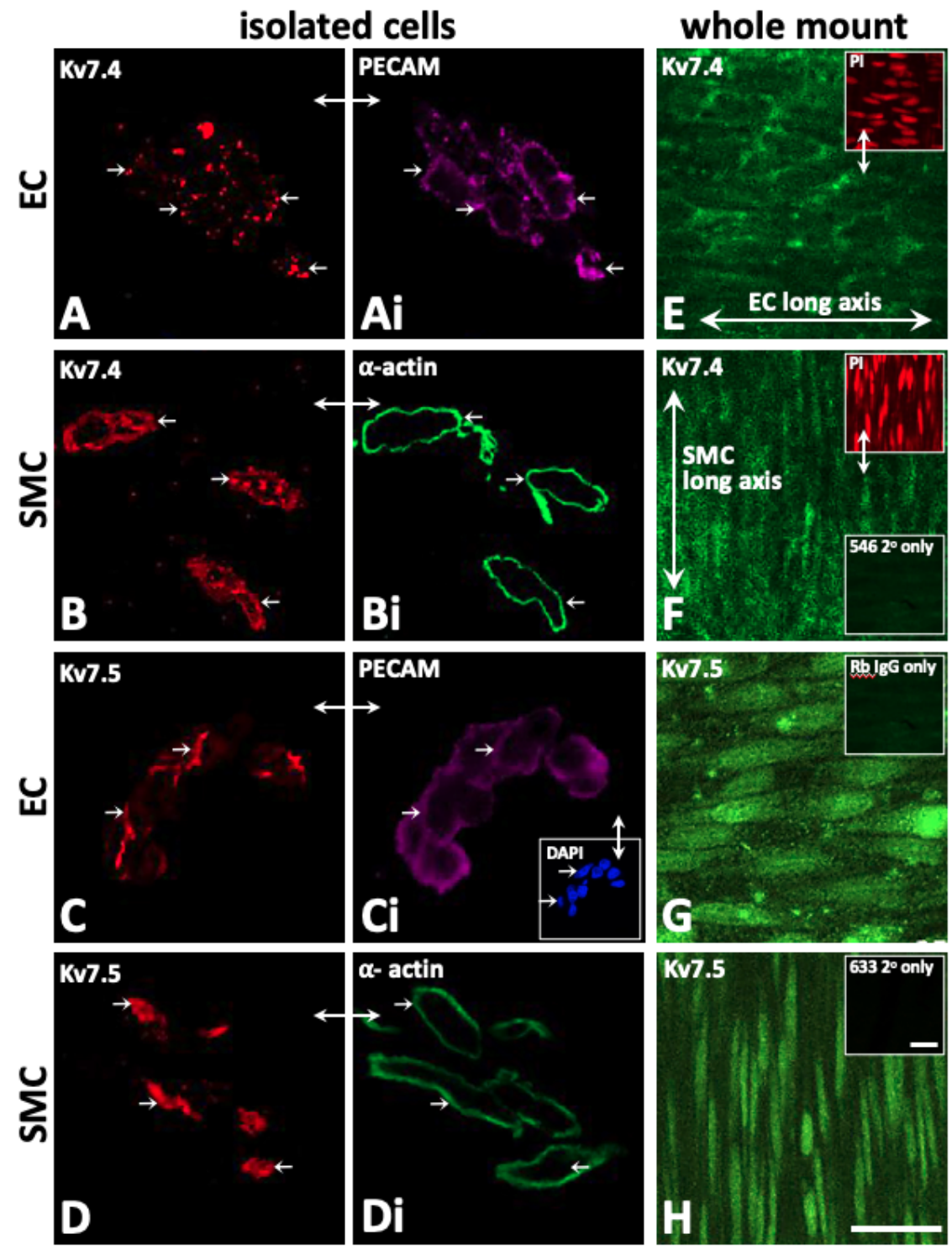



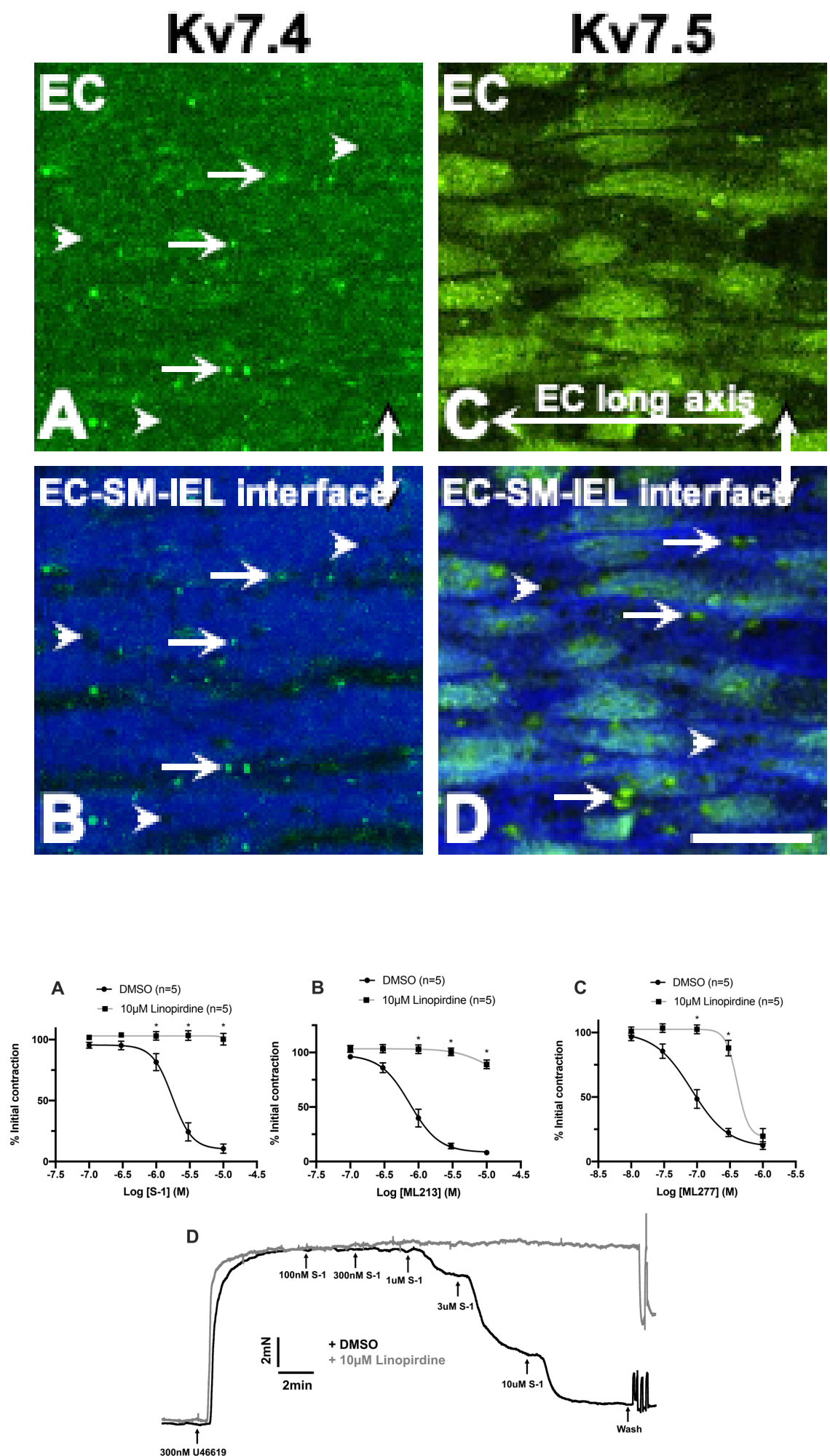

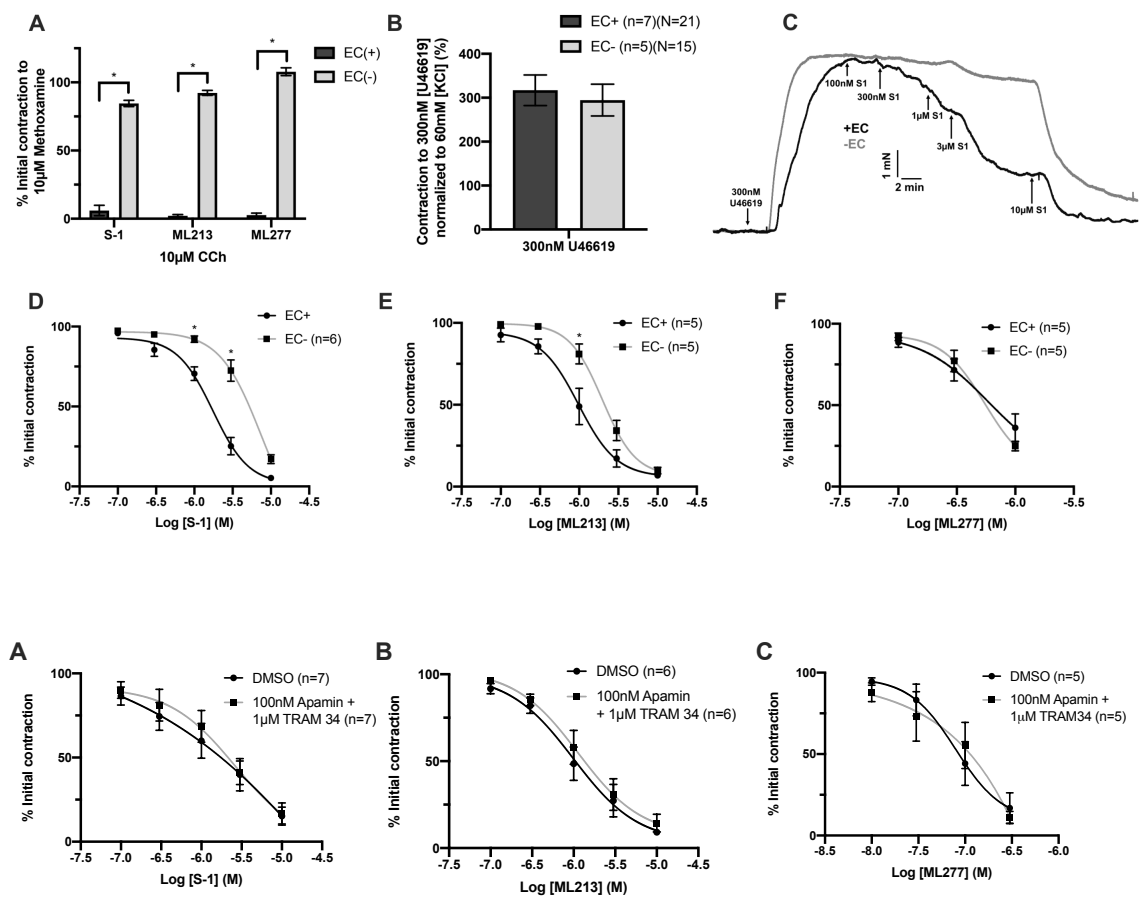
$100 \mu \mathrm{M} \mathrm{BaCl}$
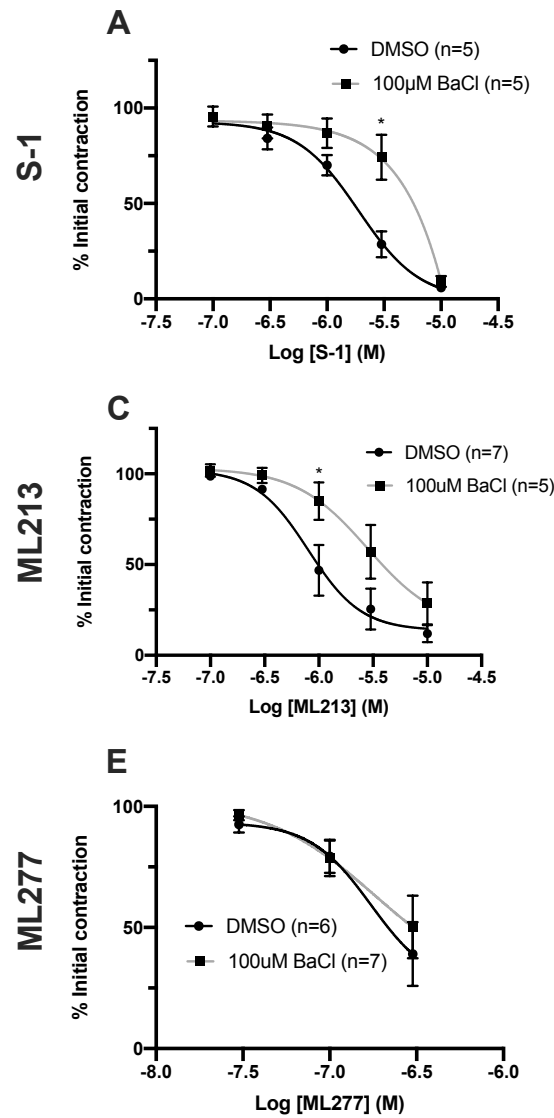

G

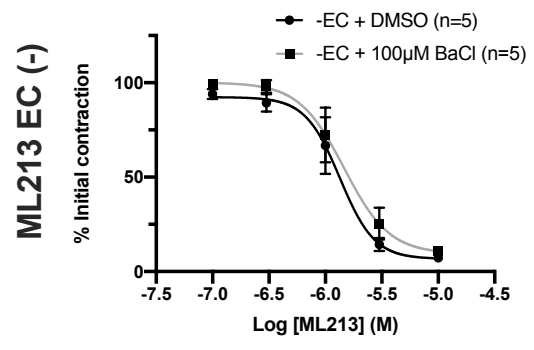

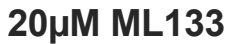

B

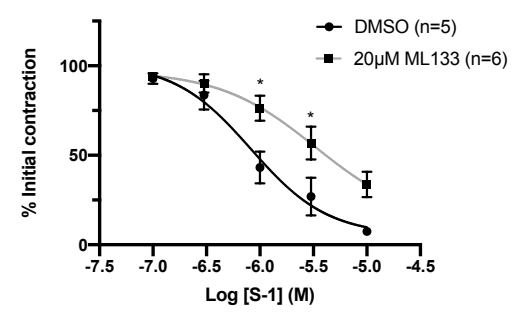

D

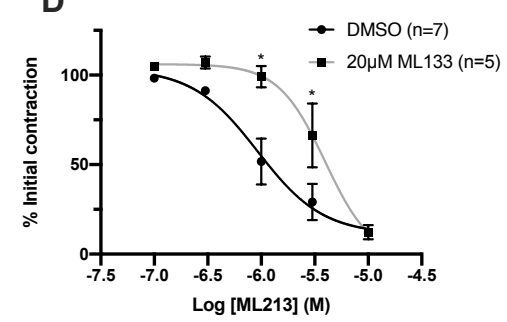

F

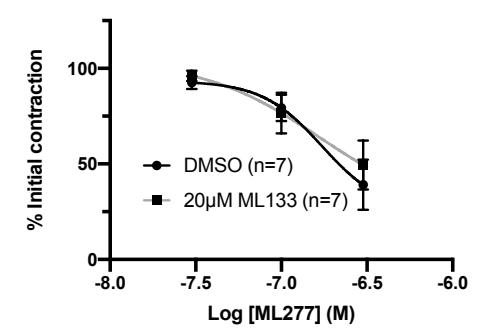

H

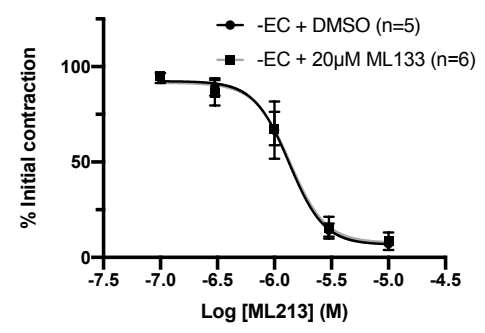



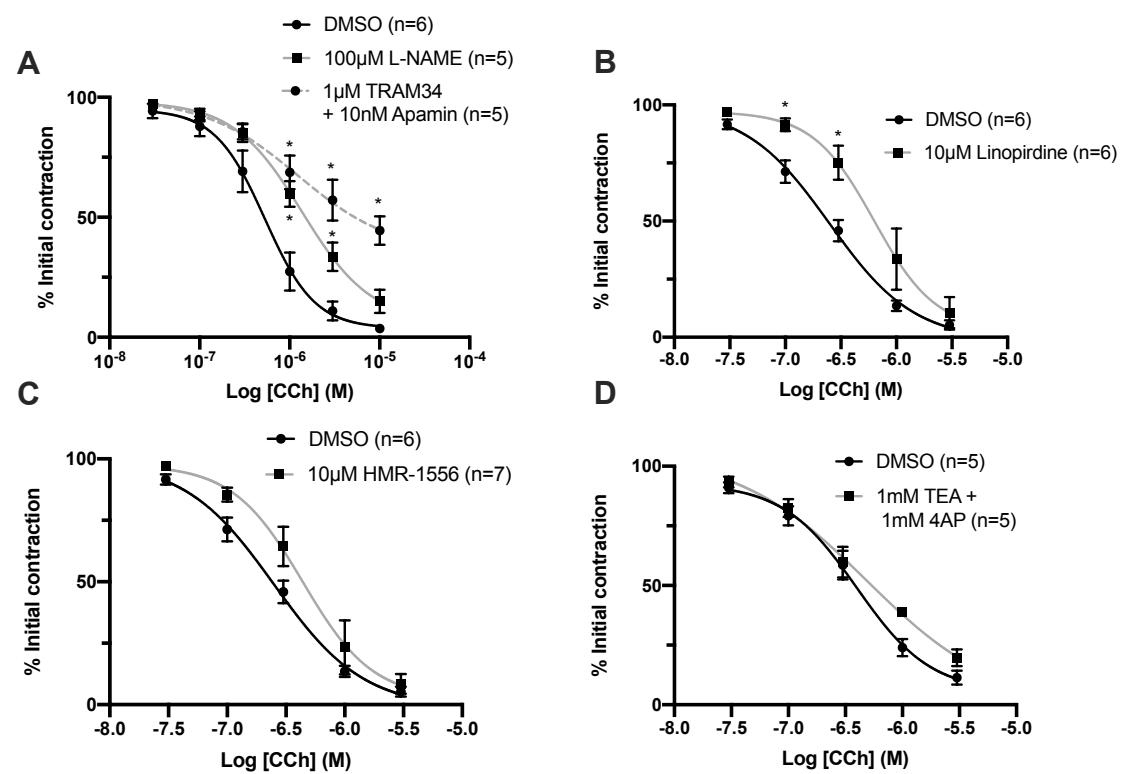

E

$\rightarrow$ DMSO $(n=6)$

- 1uM TRAM34 +
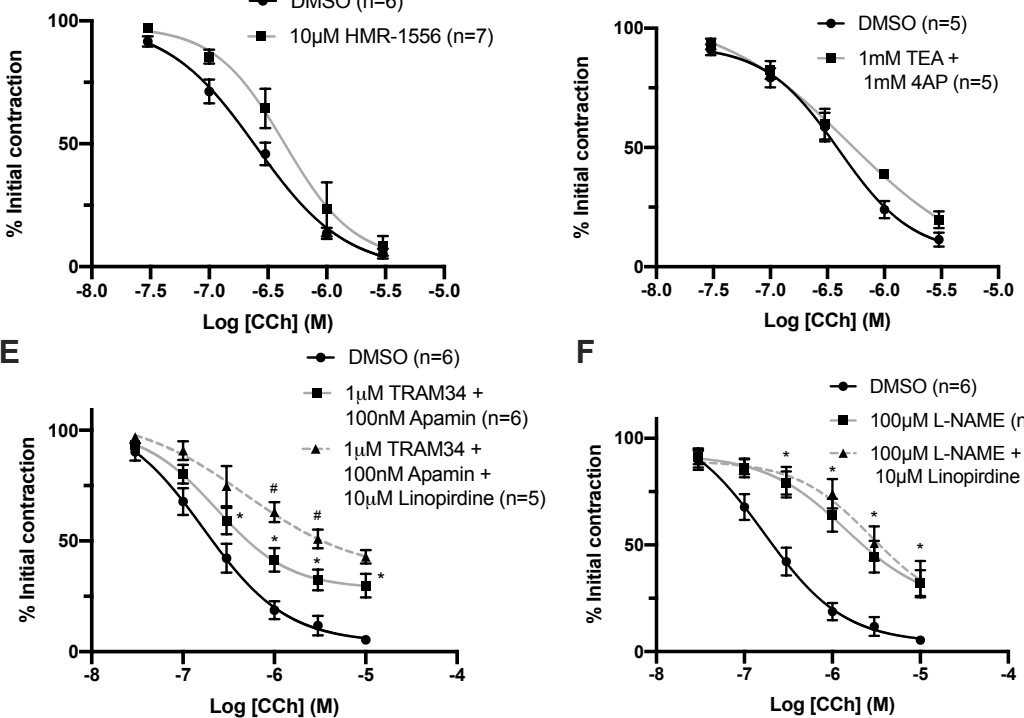

$\mathbf{F}$
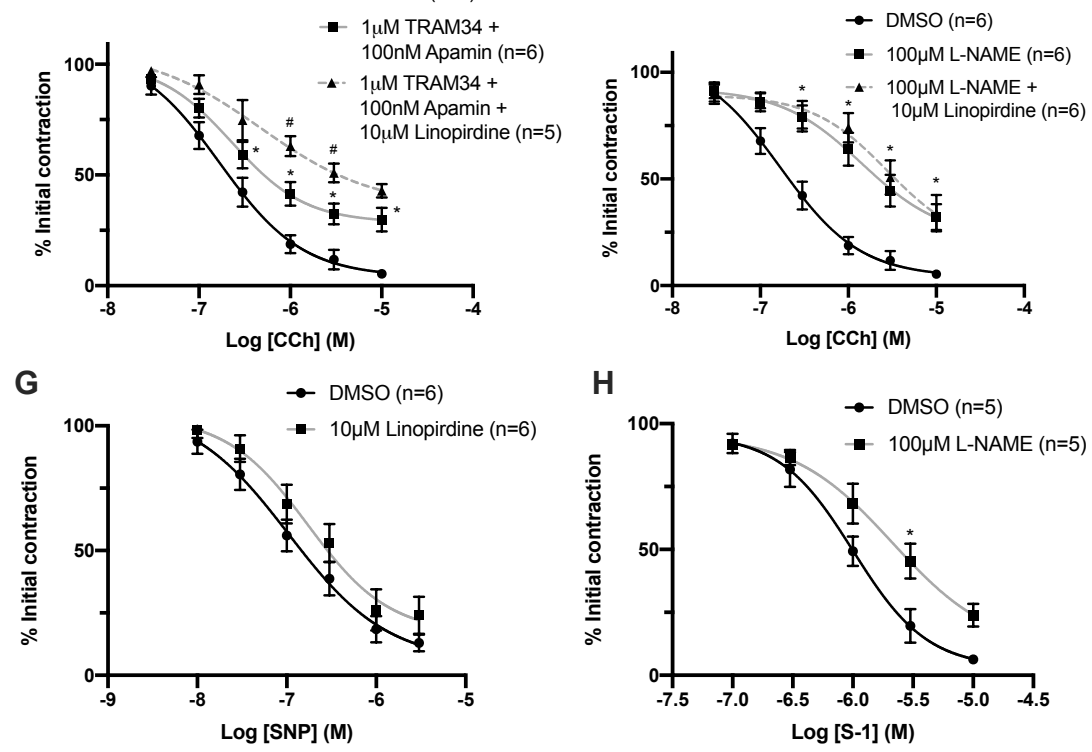


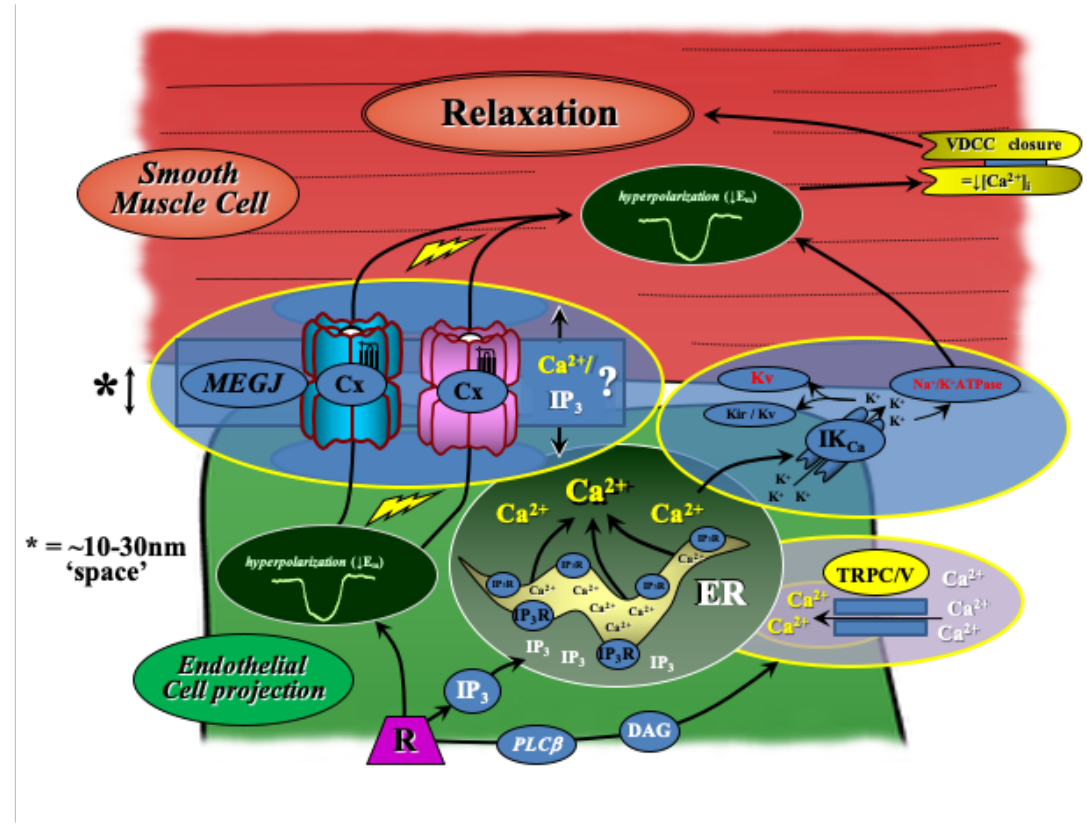

\section{Hosted file}

Baldwin 2020 Tables.docx available at https://authorea.com/users/326861/articles/454592identification-and-characterization-of-kv7-channels-within-rat-mesenteric-endothelialcells 